\title{
El gimnasio en casa (1861-1912): ¿De una moda a estilo de vida saludable?
}

\author{
Torrebadella-Flix, Xavier \\ El gimnasio en casa (1861-1912): ¿De una moda a estilo de vida saludable? \\ MHSalud, vol. 18, núm. 1, 2021 \\ Universidad Nacional, Costa Rica \\ Disponible en: http://www.redalyc.org/articulo.oa?id=237064193006 \\ DOI: https://doi.org/10.15359/mhs.18-1.6
}

Esta obra está bajo una Licencia Creative Commons Atribución-NoComercial-SinDerivar 3.0 Internacional. 


\section{El gimnasio en casa (1861-1912): ¿De una moda a estilo de vida saludable?}

\section{The Gymnasium at Home (1861-1912): From a Fashion to a Healthy Lifestyle? \\ Academia em casa (1861-1912): da moda ao estilo de vida saudável?}

Xavier Torrebadella-Flix

Universidad Autónoma de Barcelona, España

xtorreba@gmail.com

(iD http://orcid.org/0000-0002-1922-6785
DOI: https://doi.org/10.15359/mhs.18-1.6 Redalyc: http://www.redalyc.org/articulo.oa? $\mathrm{id}=237064193006$

Recepción: 16 Abril 2020 Aprobación: 14 Septiembre 2020

\section{ReSUMEN:}

En España, con la aparición de los primeros gimnasios higiénicos en la década de los años sesenta del siglo XIX, la gimnasia doméstica fue una alternativa para quienes no podían o no querían asistir al gimnasio. La industria gimnástica inventó métodos y aparatos para facilitar el ejercicio físico en casa. El objetivo de la presente aportación es dar a conocer este tipo de gimnasia y estimular un relato circunstancial y original. A través de la prensa y de la bibliografía histórica de la época hacemos la revisión pertinente hasta 1912. Finalmente, este relato sirve para concluir una problematización en el entorno de la débil cultura física de principios del siglo XX en España.

Palabras ClaVe: Actividad física, ejercicio físico, España, gimnasia.

\section{Abstract:}

When the first hygienic gymnasiums appeared in Spain, in the 1860s, home exercise was an alternative for those who could not or did not want to go to a gymnasium. The gym industry invented methods and apparatus to make physical exercise at home easier. This paper aims to describe these kinds of home gymnasiums and stimulate circumstantial and original narrative. Through the press and historical bibliographical sources of the time, we reviewed the subject in publications up to 1912. Finally, this narrative serves to conclude a problematization in the environment of Spain's weak physical culture at the beginning of the twentieth century.

KEYWORDS: physical activity, physical exercise, Spain, gymnastics.

\section{Resumo:}

$\mathrm{Na}$ Espanha, com o surgimento das primeiras academias higiênicas nos anos 60 do século 19, a ginástica doméstica era uma alternativa para quem não podia ou não queria frequentar a academia. A indústria da ginástica inventou métodos e aparelhos para facilitar o exercício físico em casa. O objetivo desta contribuição é divulgar este tipo de ginástica e estimular uma história circunstancial e original. Através da imprensa e da bibliografia histórica da época, fazemos a resenha pertinente até 1912. Por fim, esta história serve para concluir uma problematização no ambiente da débil cultura física do início do século XX, na Espanha.

Palavras-chaVe: atividade física, exercício físico, Espanha, ginástica.

\section{INTRODUCCIÓN}

Con el desarrollo y la difusión de los primeros gimnasios higiénicos constituidos a partir de los años sesenta del siglo XIX, las clases acomodadas tuvieron a su alcance la posibilidad de confiar su desarrollo corporal y bienestar físico a un experimentado profesor o profesora de gimnástica (Vicente-Pedraz y Torrebadella-Flix, 2019; Torrebadella-Flix, Rivero-Herraiz y Sánchez-García, 2019). En estos establecimientos anunciados como "higiénicos", y que solían disponer de la orientación de algún personal facultativo médico, se atendía un ejercicio físico que llamaban racional y metódico con el objeto de preservar o restablecer la salud (Torrebadella, 2014).

Puede decirse que en esta época, en casi todas las ciudades importantes de España, había algún que otro gimnasio dirigido por un reputado profesor o profesora, eso sí, con la supervisión de personal facultativo médico. Como sucedía en diversas partes de Europa, en España el negocio de la gimnástica también empezó 
a ser rentable y fue en aumento, sobre todo a partir de aquella generación de hombres y de mujeres que obtuvieron el título oficial en aquella efímera Escuela Central de Profesoras y Profesores de Gimnástica (1887-1892) que cerró por falta de presupuesto (Pastor, 1997). Si la desventura de este suceso perjudicó a un cierto desarrollo de la cultura física en el país, por otra parte, se demostró la incapacidad política de los sucesivos gobiernos de querer progresar al ritmo de las naciones modernas. Sin embargo, estas primeras profesoras y profesores de gimnástica alimentaron también la fundamentación de los discursos regeneracionistas de la crisis finisecular del llamado "Desastre" del 98 y se involucraron en la propagación de la gimnástica y de la educación física en general (Torrebadella y López-Villar, 2016).

Los primeros gimnasios higiénicos para "ambos sexos" crecieron con la protección de las ciencias terapéuticas y, también, de algunos tratados de gimnástica que se presentaron como la solución a la degeneración de la especie humana, es decir, para recuperar la salud y aliviar las dolencias físicas y nerviosas, y otros vicios de conformación que afectaban sobre todo a las personas adsorbidas por los ajetreos de la vida urbana (Torrebadella, 2011).

La gimnasia higiénica entró en la configuración urbana de una sociedad moderna inmersa en un proceso científico y tecnológico a caballo de la revolución industrial. La rápida transformación de las clases medias y el protagonismo de una vida social burguesa más abierta y cosmopolita, eso sí, muy preocupada por el bienestar corporal y la salud, puso de moda la gimnástica y, con ella, el anhelo romántico de la belleza y de la eterna juventud (Un viejo setentón, ca.1899, p. 65). Por lo tanto, la gimnasia se presentó, pues, como la solución más efectiva y menos dolorosa para luchar contra las muertes prematuras; con lo cual, como mencionaba el gimnasiarca José Sánchez Somoano (1883a, p. 13), "la inacción no trae consigo más que enfermedades, y éstas la degeneración de las razas”. Véase, además, que mencionaba José Hernández Ardieta (1838-1912), exsacerdote murciano, libre pensador y creador del primer colegio de la Institución Libre de Enseñanza en Cataluña -Sabadell- y fundador del semanario obrero Los Desheredados (Masjuan, 2006):

En la época en que vivimos se encuentran muchas personas anémicas, nerviosas, débiles y enfermizas por falta de ejercicio material. Mientras que estas prácticas se descuiden, sin comprender que el desarrollo físico es condición indispensable para la salud, la humanidad ira degenerando hasta convertirse en una familia de tísicos entecos e inútiles, devorados por las enfermedades y degenerados en sus condiciones morales. (Un viejo setentón, ca.1899, p. 65).

Con los nuevos gimnasios también llegaron los miedos a los accidentes, de aquí que los gimnasiarcas de la época procurasen desterrar los ejercicios funambulescos para serenar a las madres y padres de familia (Vicente-Pedraz y Brozas-Polo, 2017). La gimnástica higiénica y racional nada tenía que ver con aquella que exhibían las compañías gimnástico-acrobáticas. Efectivamente, como indica Pastor Pradillo (2015, p. 129): "paulatinamente, la evolución metodológica de la gimnástica fue desechando las grandes máquinas en beneficio de los aparatos o instrumentos más manejables y, sobre todo, de más fácil uso en locales cerrados".

Alrededor de la gimnástica se establecieron nuevas formas de negocio. Una era la de ejercer de profesor o profesora en los colegios; otra la de invertir en la invención y fabricación de materiales y aparatos gimnásticos; también había quien escribía tratados y, otras personas, como hemos citado, dedicaron los mejores años de su vida a viajar por el mundo en compañías gimnásticas. Ahora bien, al gimnasio moderno le salió un poderoso contendiente, la gimnástica doméstica o casera, es decir, el ejercicio físico con una finalidad higiénica y en el domicilio particular de la ciudadanía. Surgía así una tendencia que desde entonces no ha dejado de reinventarse en la sociedad contemporánea.

Como trataremos seguidamente, la profesión gimnástica inventó una serie de métodos y técnicas de fácil ejercitación que no requerían de una presencia experta. En esta amalgama procedimental aparecieron una diversidad de aparatos, relativamente sencillos y manejables que facilitaron la ejercitación. Aparte, también aparecieron algunos sistemas o tipos de gimnástica, que de igual modo satisfacían los intereses de aquellas personas, que por el motivo que fuere, no podían asistir al gimnasio y decidían ejercitarse en casa o en el trabajo. Así pues, el objetivo de este artículo es dar a conocer este tipo de ejercitación física que fue conocida con el nombre de gimnástica -gimnasia- "doméstica" o "casera" y que empezó a desarrollarse a mediados del 
siglo XIX. Este estudio se cierra en 1912 por ser considerado un año de inflexión que marcó en la sociedad española el triunfo normativo de la gimnasia sueca.

El trabajo se ha elaborado a partir de la revisión de fuentes documentales en la prensa histórica de la Hemeroteca Biblioteca Nacional de España (HBNE), el Arxiu de Revistes Catalanes Antigues (ARCA) y, además, se han localizado obras de referencia histórica en el Repertorio bibliográfico inédito de la educación física y el deporte en España (1800-1939) (Torrebadella, 2011). El tratamiento de las noticias se ha elaborado en un enfoque positivista y de exposición cronológica, y para la hermenéutica se han consultado algunos trabajos de relación en torno al objeto de estudio.

\section{Desarrollo [1]}

Desde la década de los sesenta del siglo XIX, el gimnasio higiénico irrumpió en toda Europa y en América. El moderno ejercicio físico se estructuró en una significativa variedad de movimientos de todo tipo, regulados por el artificio de la aparición de las máquinas gimnásticas. Estas máquinas, además de facilitar el movimiento, proporcionaban una mayor seguridad y economía gestual.

Entre las muchas máquinas inventadas, las de poleas fueron las más conocidas, ya que tenían la ventaja de poder ser utilizadas en el espacio privado, es decir, en el hogar. Así se introdujeron en el mercado las primeras máquinas gimnásticas por poleas como la inventada, en 1859, por los franceses de René Vian y Josep Charles Burlot, los cuales ya disponían en París -en 1862- de un comercio de máquinas gimnásticas de salón en la Rue Roussell, 21 (Schreiber, 1884) (Ver Figura 1).

Las máquinas de Burlot y Vian podían llegar a ser también muy complejas, como la que se trajo de París el gimnasiarca Víctor Vignolles (Busqué y Torró, 1865), para el lujoso gimnasio que tenía abierto en Madrid desde 1861. Al respecto, se mencionaba lo siguiente:

Esas grandes máquinas de combinación y de contrapesos graduados que hoy han llegado a la perfección en París, son importadas de los Estados Unidos. No son, como se ha dicho, invención de Mr. Vignolles acaso por haber sido el primero que las trajo a Madrid. Antes de que él pensara dedicarse a la Gimnasia, ya existían esas máquinas. (Sánchez Somoano, 1883b, p. 54)

Estas máquinas fueron divulgadas en algunos tratados de gimnástica de la época. La lujosa máquina de Burlot, por ejemplo, fue expuesta en el tratado de Esteban García-Fraguas (1894).

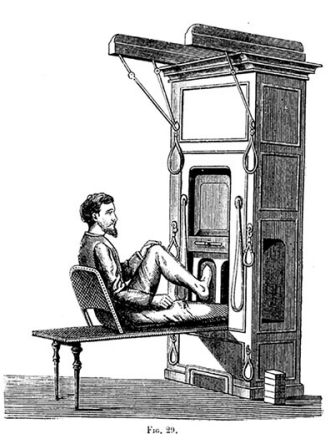

FIGURA 1

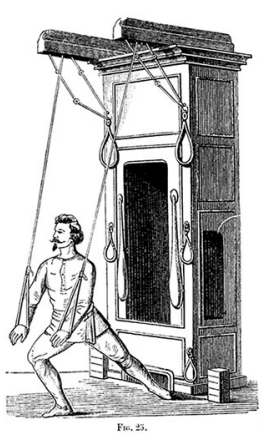

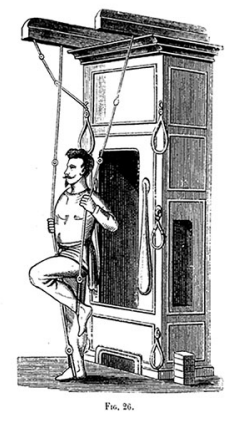

s.

Máquinas gimnásticas de René Vian y Josep Charles Burlot

Nota: Imágenes de Traité pratique de massage et de gymnastique médicale por Schreiber (1884, p.89, p.85, p.86) Octave Doin. En Dominio Público.

En Londres se presentó el gimnasio portátil de Gustav Ernts (1861). Se trataba de un aparato que podía facilitar numerosos ejercicios para todas las partes del cuerpo (Ver Figura 2). Este tipo de aparatos solían exponerse en certámenes y exposiciones internacionales. 

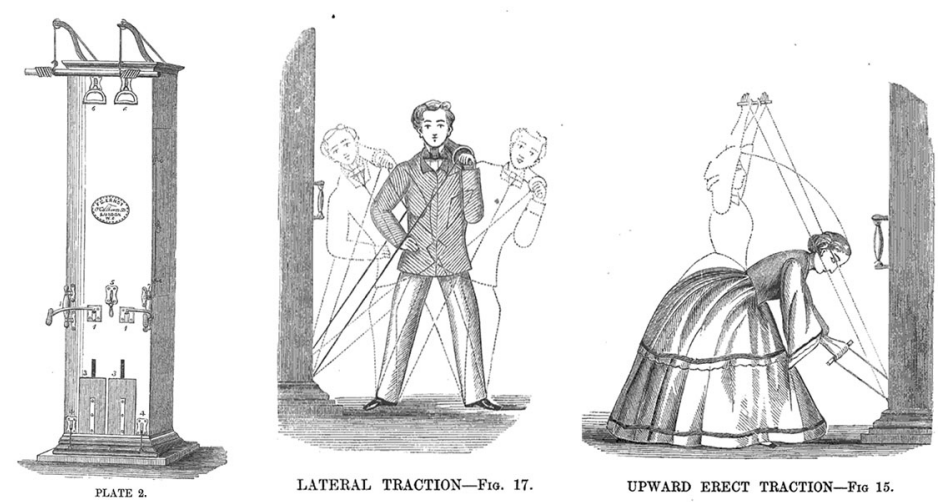

FIGURA 2

The Portable Gymnasium

Nota: Imágenes de: The Portable Gymnasium: A Manual of Exercises, Arranged for Self-Instruction in the Use of the Portable Gymnasium, por Ernst (1861, p. 11, p. 57 y p. 53). Grant \& C'. En Dominio Público.

Pero no todo era utilizar estas máquinas. El primero en divulgar un método de gimnasia sin aparatos fue el alemán Daniel Gottlob Moritz Schreber (1808-1861), profesor de medicina interna y de farmacología en la Universidad de Leipzig y, posteriormente, director del Instituto Ortopédico; fue considerado uno de los patronos de la gimnástica sueca en Prusia. En España presentó el Manual popular de gimnasia de sala (1861) que, según Torrebadella (2014), fue la obra más conocida del siglo XIX y la que acreditó una confianza en la "gimnástica médica". Los ejercidos de Schreber eran muy sencillos y podían ser realizados en cualquier lugar, en la misma casa o en el trabajo, aunque siempre era preferible al aire libre (Figura 3). Cada ejercicio tenía su orientación médica, es decir, su aplicación curativa o benefactora para el organismo.

Digamos que esta obra creó el imaginario que proclamaba que con la gimnástica se podían curar muchos males. De aquí que los gimnasios la incorporasen puesto que, además, era ideal para aquellas personas con un sedentarismo preocupante. Naturalmente, toda persona sedentaria con solo media hora de ejercicio diario mejoraba rápidamente la condición física y su aspecto. El Manual de Schreber fue muy acreditado y, como indica Torrebadella (2014), tuvo muchos imitadores (Anónimo, 1885; De Vallieres, ca. 1907; Paz, 1888; Ugarde, 1906). El profesor de gimnástica Eusebio Ferrer (1894) recomendaba esta obra a sus estudiantes del Instituto de Mahón por tratarse de un buen procedimiento para la gimnasia de "sala o casera".

Como indica José Luis Pastor (2001, p. 234), con la idea de la gimnasia de sala nacía "la fórmula capaz de convertir el domicilio en un gimnasio lo que abría posibilidades hasta entonces inéditas para el diseño y venta de nuevos materiales".
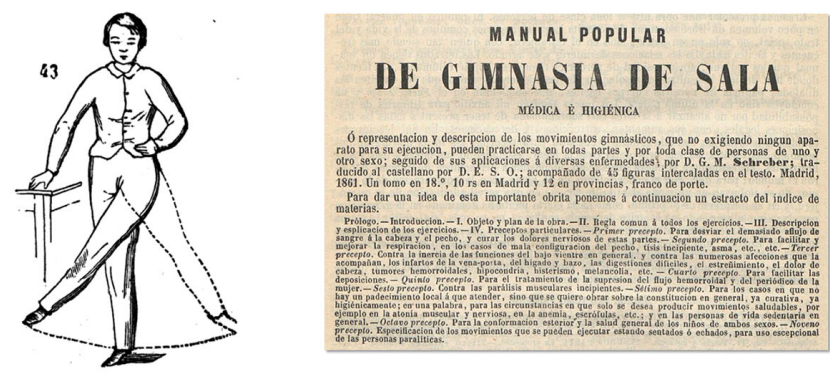

FIGURA 3

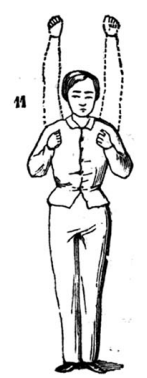

El Monitor de la Salud, Madrid, 15 de agosto de 1861. Ejercicios de gimnasia de sala Nota: Imágenes de Schreber (1864, p.122, p.70). En Dominio Público. Manual Popular de Gimnasia de sala, (Bailly-Baillière, 1861, p.75, https://ddd.uab.cat/record/174100) Colección HBNE: CC-BY-NC-SA 4.0

Además, este tipo de gimnasia, por la facilidad de los ejercicios, se consideró perfecta para desenvolver la disciplina del alumnado y educar en el control de la voluntad. Así, estos ejercicios, que en la gimnasia 
sueca se llamaron "ejercicios de orden", fueron comúnmente abusados en la enseñanza de la educación física tradicional (Pastor, 1997, p. 512); incluso podían realizarse en la misma aula y, por supuesto, no entrañaban peligros:

La gimnasia de sala consiste, en series de movimientos libres y ordenados para poner en acción todos, o casi todos, los músculos del cuerpo, y dar cierta actividad a los órganos, de manera que se desarrollen armónicamente, y, facilitándose la circulación de todos los humores, se eviten muchas enfermedades, dándonos elementos de salud y robustez. Para ella, no son necesarias ni se emplean instrumentos, máquinas, ni aparatos de ningún género. Están, pues, proscritas las anillas, las cuerdas, las barras, las paralelas bajas y altas, etc., y desde luego, con mayor razón, los famosos trapecios. (Sardá, 1882, p. 225)

En España, fueron también conocidos los populares resortes de muelles que ideó Jules-Léandre Pichery (1857). El primero que se ocupó de este ingenioso y utilitario aparato fue el doctor Busqué y Torró (1865), que lo conoció en el gimnasio de Mr. Vignolles (Figura 4):

Ciertamente no ofrece los excelentes y poderosos recursos de la gimnasia moderna: pero a las ventajas de todos los trabajos a pie firme en que para la estabilidad y firmeza se necesita poner en juego todos los extensores y flexores del tronco y piernas, reúne la facilidad y la comodidad de fijar este sencillo aparato en cualquier parte, al aire libre, en una habitación, gabinete, despacho, baño, etc. y sin salir de su aposento el hombre de bufete, el literato, el filósofo, pueden desperezar sus miembros entorpecidos por una larga vigilia o trabajo mental, reanimar su lenta circulación sanguínea, desarrollar el calórico, promover el sudor y adquirir soltura en la locomovilidad general y parcial. (Busqué y Torró, 1865, p. 56)


FIGURA 4

"Ejercicios con resortes de muelles de Pichery"

Nota: Imágenes de Gimnástica higiénica, médica y ortopédica o el ejercicio considerado como medio terapeútico por Busqué y Torró (1865, p.157). Manuel Galiano. En Dominio Público.

Posteriormente, Ph. J. B. Carue, el más importante fabricante y proveedor de aparatos de gimnástica que existía en Francia y reconocido internacionalmente, presentó el Tratado práctico de gimnástica higiénica para ambos sexos (Carue, 1880) -cuya primera edición francesa es de 1868-. En esta obra de 52 páginas aparecen el detalle de 26 ejercicios - tensores, mazas y pesas-, entre estos los populares resortes de muelles de Pichery (Figura 5), pero perfeccionados al substituir los muelles por cordones elásticos. 
MHSALUD, ISSN: 1659-097X, 18(1), ENERo-Junio, 2021, PP 1-30

TORREBADELLA-FLIX
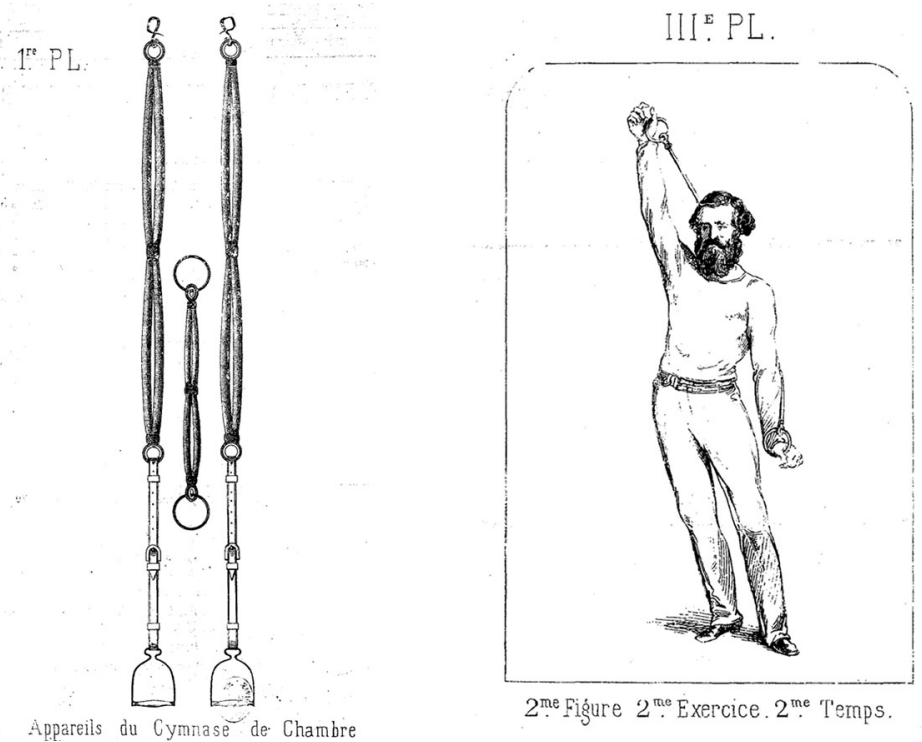

FIGURA 5

Resortes de muelles Pichery

Nota: Imágenes de Traité Practique du Gymnase de Chambre. Hygiénique et Médical.

A L'usage des Deux Sexes por Carue (1868, p. I, p. III). Paris. En Dominio Público.

El Tratado Carue consiste en una propuesta de ejercicios realizados con los aparatos del autor (tensores) y con distintas formas de pesas. Era una obra sencilla destinada a popularizar la gimnástica y hacerla accesible a todo tipo de personas (Figura 6).

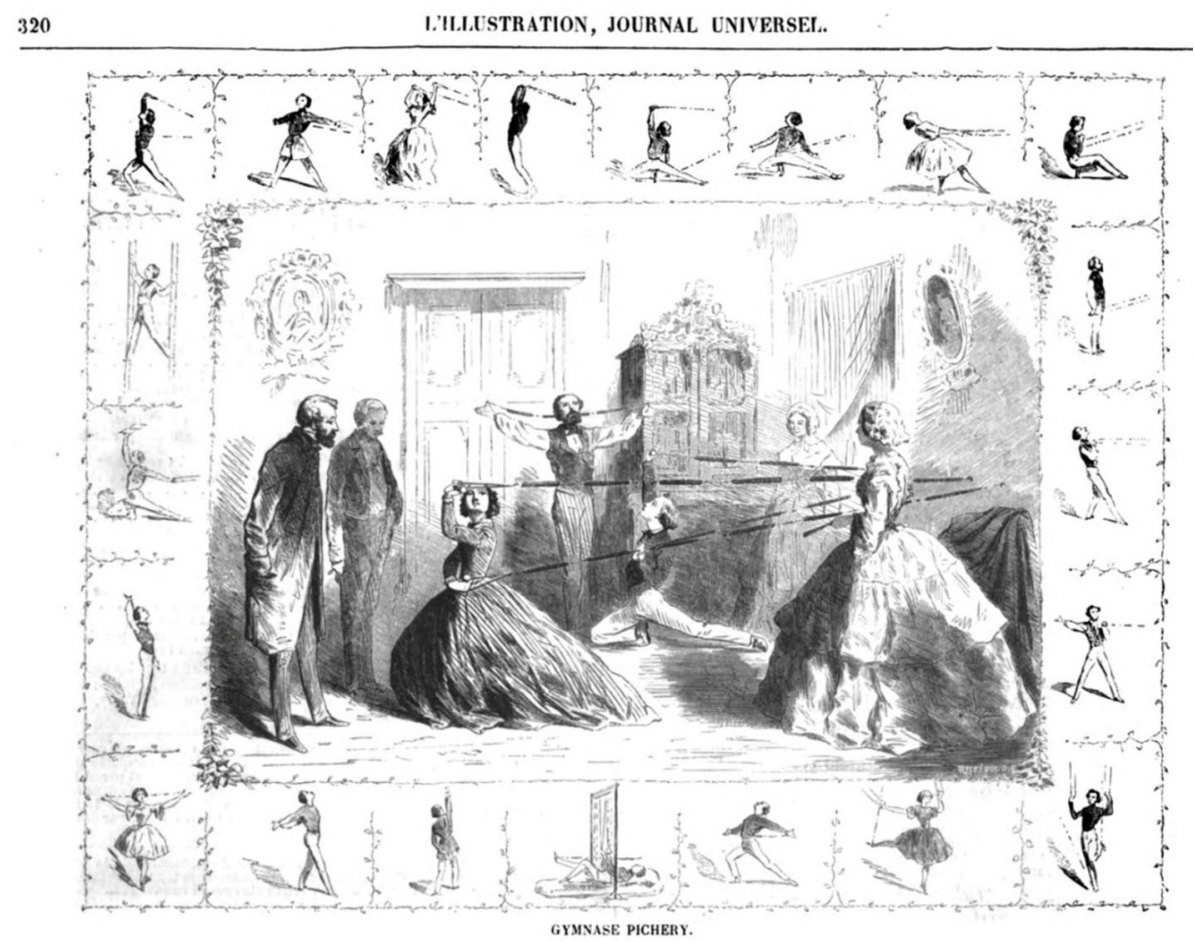

FIGURA 6

Gymnase Pichery

Nota: Imagen de L'Ilustration, Journal Universel (13 de noviembre de 1858, p.320). En Dominio Público. 
El profesor sevillano Salvador López Gómez (1873), fundador en 1873 del Centro de Educación Física, Profiláctico y Terapéutico (Ávila, 2013), consideraba ventajoso y avanzado el uso de las máquinas de poleas y, también, se inclinaba por el sistema Pichery. Curiosamente, en este mismo año se difundía el "Gimnasio doméstico graduado" inventado por el francés Eugenio Paz (1873a, 1873b), que disponía del mejor establecimiento gimnástico de París (Torrebadella-Flix, 2020) (Figura $7^{[2]}$ ).

Aparato higiénico y médico por el cual pueden ejercitarse racional y armónicamente todas las partes del cuerpo.

Este aparato de forma y aspecto elegantes, y que apenas ocupa el sitio de una alacenita, facilita todos los movimientos y posiciones del cuerpo, ejercitando sucesivamente todos los grupos musculares o localizando, si se quiere, el ejercicio, ya de un miembro, ya de una articulación.

No podemos presentar aquí más que un corto número de movimientos que pueden desarrollarse con nuestro aparato. Las personas que deseen recibir el prospecto que los contiene todos, con las dimensiones y precios de la máquina, pueden dirigir su pedido al Sr. Paz, director del Gran Gimnasio, rue\# des Martyrs, 34, París. (Paz, 1873a, p. 698)
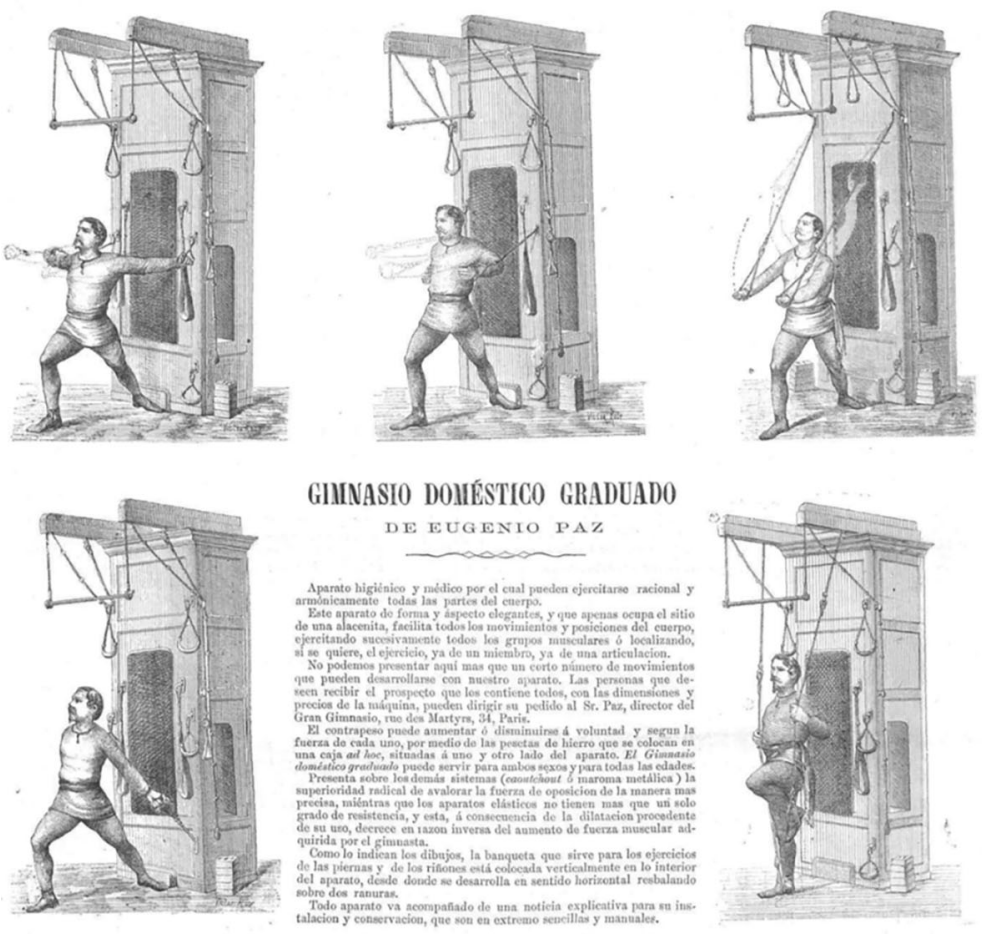

GIIINASI0 D0uÉsTIC0 GRADUAD0
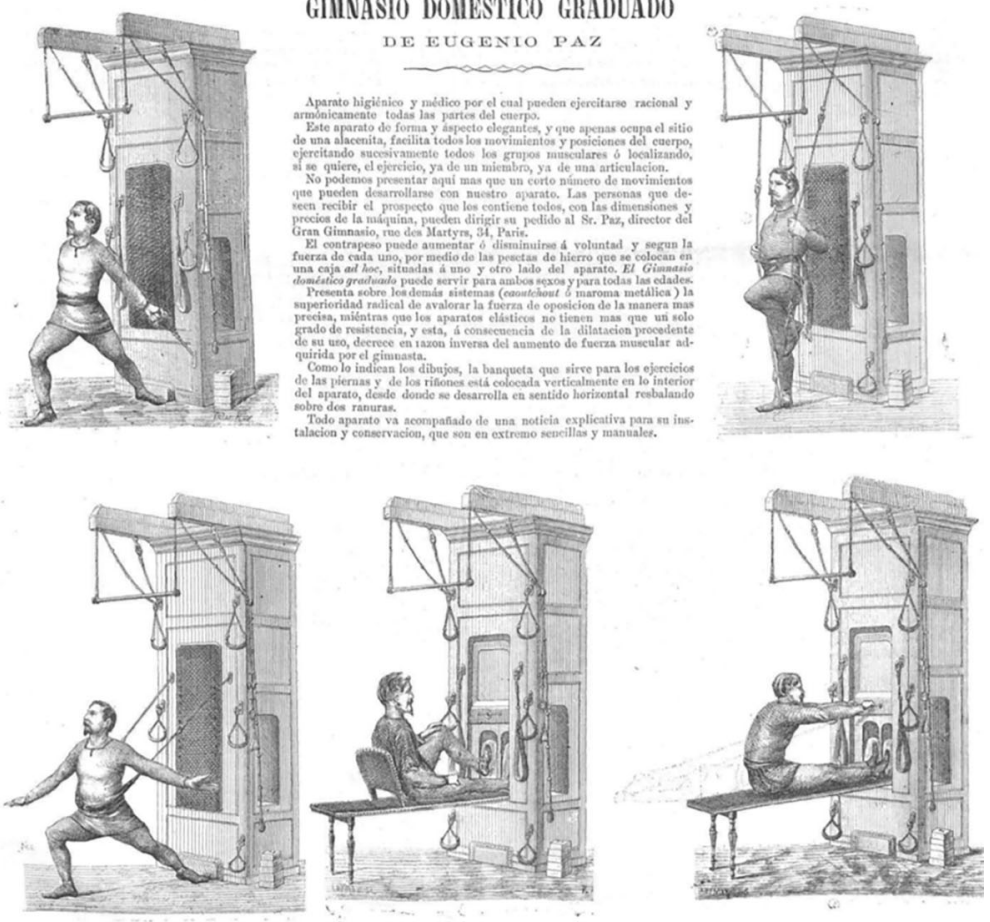

FIGURA 7

Gimnasio doméstico graduado

Nota: Imagen de El Americano (27 de enero de 1873, p. 748, http://hemerotecadigital.bne .es/issue.vm?id=0004274658\&search=\&lang=es). Colección HBNE: CC-BY-NC-SA 4.0.

Por su parte, desde Nueva York, el político cubano José Martí (1853-1895) escribió en 1883 un artículo en La América recomendando el "gimnasio doméstico" inventado por los hermanos Gifford (Herrera, 
2018). Este ingenioso y estructurado aparato era una demostración de la pericia inventora que desbordaba el ambiente gimnástico norteamericano, y en el que la mujer aparecía como blanco comercial.

\footnotetext{
En suma, no hay ejercicio corporal, ya de los suaves que llaman calisténicos, ya de los más recios que se enseñan como gala en los gimnasios, que merced a este excelente y airoso aparato de Gifford, no pueda hacerse sin incomodidad alguna en la propia casa.

Para nuestras mujeres pudorosas, a quienes simpáticas razones vedan la asistencia a los gimnasios públicos, y que necesitan, sin embargo, tan grandemente de estos ejercicios, el Gimnasio Doméstico es de inapreciable ventaja: sin exponerse a ojos extrañaos, y en su propia habitación, pueden ejercitarse diariamente en todos los movimientos saludables que aumentaron la fortaleza de sus músculos, y la armonía y gracia de sus formas. (Martí, 1883, p. 240)
}

Los ejercicios con poleas fueron divulgados como uno de los mejores sistemas de "gimnástica doméstica"; sus movimientos no necesitaban de grandes exigencias físicas, se podía aplicar para todo tipo de personas. Por lo que se refiere a España, el gimnasiarca José Sánchez González de Somoano debe ser reconocido como el primer inventor de una máquina gimnástica de poleas. En 1886 presentó el Nuevo método de gimnástica racional con la polea sistema Sánchez con patente de invención para veinte años (Sánchez Somoano, 1886) (Figura 8). Consistía en un sencillo manual que trata los ejercicios mediante el aparato de Poleas Sánchez, inventado en 1875. Este aparato recibió la patente correspondiente del Ministerio de Fomento y con él se añadía un manual de uso. El aparato se colocaba clavado en la pared y disponía de una colección de pesas graduadas, de 50 gramos en adelante. El precio oscilaba, según el tipo, entre 100, 125 y 150 pesetas.

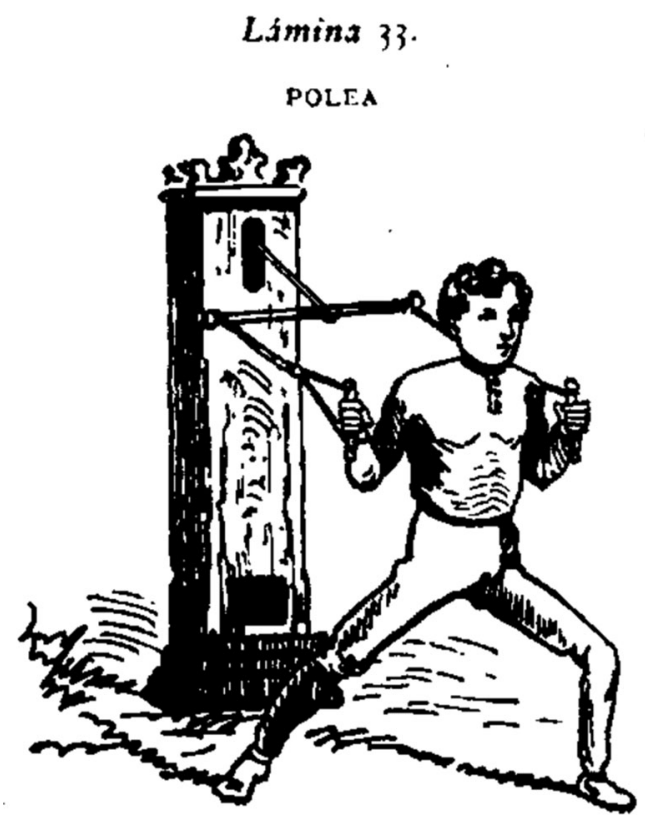

Figura 31.

\section{FIGURA 8}

"Este aparato, perfeccionado en Madrid por el autor de este TRATADO en el año de 1875, estando el Gimnasio establecido en la calle de las Infantas, se ha extendido desde aquella época con prodigiosa rapidez por Gimnasios, Colegios y casas particulares, a pesar de las críticas de que era objeto por parte de algunos Profesores, que también han tenido que adoptarle en vista de sus resaltados.”

Nota: Imagen de Tratado de Gimnasia Pedagógica para uso de las escuelas de primera y segunda enseñanza e institutos por Sánchez Somoano (1883b, p. 115). Colección HBNE: CC BY NC SA 4.0.

El sistema de poleas era publicitado como un completo gimnasio doméstico de uso particular, sencillo y sin peligros, podía ser utilizado por todo tipo de sujetos: personas ancianas, niñez y señoras (Figura 9). Los setenta ejercicios que completaban el sistema Sánchez se organizaban en siete series, y se trabajaban todos los 
grupos musculares: I. Ejercicios de dilatación torácica en la posición de pie firme. II. Ejercicios generales en la posición firme. III. Ejercicios parciales en la posición firme. IV. Ejercicios de dilatación torácica, sentados. V. Ejercicios generales, sentado. VI. Ejercicios parciales, sentado. VII. Ejercicios generales, acostado. Mas tarde José Sánchez publicó, sobre este aparato, el libro Gimnasia doméstica. Poleas (Sánchez Somoano, 1895).


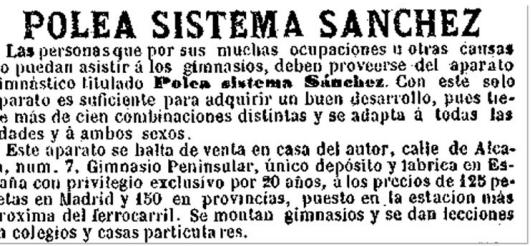

n colegios y casas particutares.
nimnasios y se dan lecciones
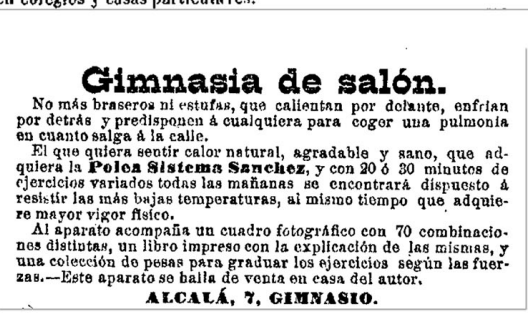

\section{FIGURA 9}

Collage sobre anuncios de la "Polea sistema Sánchez":

Nota: El Liberal, 7 de abril de 1887, p. 4 (http://hemerotecadigital.bne.es/issue.vm?id=0001153576\&page=4\&sear ch=Polea\&lang=ca). El Liberal, 10 de marzo de 1889, p. 4 (http://hemerotecadigital.bne.es/issue.vm?id=00011762 61\&page=6\&search=Polea\&lang=ca). Diario oficial de Avisos de Madrid, 6 de marzo de 1891, p. 4 (http://hemerote cadigital.bne.es/issue.vm?id=0000611061\&search=\&lang=es). La Época, 13 de enero de 1892, p. 4 (http://hemero tecadigital.bne.es/issue.vm?id=0000552099\&search=\&lang=es). Anuncios: Colección HBNE: CC BY NC SA 4.0.

Con este sistema, José Sánchez pretendía, aparte del interés comercial, difundir el ejercicio físico para todas aquellas personas que no podían asistir a los gimnasios y demostrar que con otros métodos también se podían conseguir grandes beneficios físicos, sin tener que recurrir a los mal aconsejados aparatos gimnásticos:

La propaganda que con este aparato hemos hecho desde la época ya citada, la dejamos a la pública consideración, pues basta decir que antes, tratándose de gimnasia, no se hablaba más que de trapecios, torniquetes, pesas y paralelas. Hoy, antes que todo esto, se habla de poleas, y nadie encontraría completo un gimnasio que careciese de ellas. Éste es el resultado de nuestra propaganda, hecha teórica y prácticamente; pues hemos sido los primeros en desterrar del gimnasio, o, mejor dicho, en no usar nunca en nuestros gimnasios el trapecio, la barra fija ni otros muchos aparatos, más perjudiciales que beneficiosos para el desarrollo físico. (Sánchez Somoano, 1886, pp. 3-4)

Además, volviendo a la gimnasia de sala, este profesor era partidario de su uso y, naturalmente, la recomendaba expresamente para las mujeres:

La gimnasia de sala, en la cual se pueden incluir los ejercicios de pesos pequeños y mazas, debiera hallarse más extendida, principalmente entre el bello sexo, por el poco ejercicio que hace, dada la índole de sus ocupaciones en el hogar doméstico, y por una necesidad fisiológica que debieran tener muy en cuenta todos los padres de familia desde que sus hijas llegan á los doce años hasta que pasan de los dieciséis.

Pero entre el poco ejercicio que hacen en la edad que más lo necesitan, y el uso de ese inquisitorial aparato llamado corsé, con el que pretenden dar forma al pecho, sin tener pecho para darle forma, lo cierto del caso es que la tisis y algunas otras enfermedades diezman el bello sexo en lo mejor de sus años. (Sánchez Somoano, 1883b, p. 54).

Puede decirse que la titularidad de los primeros profesores oficiales de gimnástica ofreció un espacio profesional en los gimnasios y, asimismo, en las plazas que ocuparon como docentes en los institutos de segunda enseñanza, puntos en los que se irradió una parte importante de la cultura física de principios del siglo XX. Estos grupos se esforzaron por cambiar la percepción que la mayoría de la gente tenía del gimnasio: 
Es muy común el error de creer que los gimnasios son centros de peligro, más que de seguridad, y que en ellos se ve la juventud continuamente expuesta a desgracias, irreparables muchas veces. Confundiendo lastimosamente los ejercicios que componen el trabajo higiénico, con los que constituyen el recreativo. (Anónimo X, 1891, p. 313)

Con ello, si el gimnasio resultaba caro, peligroso o simplemente no había tiempo para asistir a él; como mencionaba Luis Taboada en El Imparcial y en El Diluvio de Barcelona (30 de junio de 1892, pp. 1-2), allí estaba, al alcance de todas las personas, la posibilidad de hacerse con la gimnasia casera:

\begin{abstract}
Muchas personas aficionadas a los ejercicios gimnásticos no hacen más que saltar el lecho y sin cubrirse las carnes, cogen las pesas y las levantan a la altura de la frente diez o doce veces seguidas; otros se agarran al boliche del catre y se estiran todo lo posible, para los desentumecer los músculos; algunos se lanzan por el pasillo en paños menores y dan unas cuantas carreras vertiginosas, para conseguir la elasticidad de las articulaciones, según ellos dicen. (Taboada, 1892, p. 1)
\end{abstract}

De igual modo, Luis Royo Vilanova (1867-1900) mencionaba que "se ha inventado la gimnasia casera, con o sin ayuda de las pesas de hierro que toda persona higiénica y previsora debe guardar debajo de la cama como instrumento de trabajo matinal" (Royo, 1892, p. 273). Y proseguía:

La gimnasia se impone y el gimnasta se impone mucho más, gracias a sus buenos puños. No olvidemos que la patria puede necesitar de nosotros cualquier día, y cuando la patria llama, no llama a nadie para hacer discursos, sino para repartir guantadas al audaz invasor o bien al infiel marroquí. (Royo, 1892, p. 274)

Hacia finales del siglo XIX fue habitual la venta de aparatos de gimnasia doméstica. Esteban Martínez Díaz, más conocido por ser el capitán aeronauta que con el mismo nombre se destacó a cargo de una compañía gimnástico-aerostática, daba a conocer la polea "sublime” (Martínez Díaz, 1891). En La Dinastía (8 de marzo de 1891, p. 2) aparecía la siguiente noticia:

un vecino del Ferrol ha solicitado privilegio de invención para una polea destinaba a la gimnasia en los domicilios. Esto no tiene nada de particular. Lo majestuoso del caso está en que su autor titula el invento... ¡La sublime! No hay que maravillarse de esto. Sublime llamaron los demócratas a la Junta Central del Censo, y apenas ha resultado polea.

Según su inventor, la "Polea Sublime” estaba perfeccionada para realizar más de cien movimientos y era de aplicación general para ambos sexos, jóvenes o personas adultas. Había una polea de primera clase (nikel) a 25 pesetas y otra de segunda clase (latón) a 20 pesetas (Figuras 10, 11 y 12):

La polea "SUBLIME" es de aplicación general para ambos sexos, jóvenes o adultos; dotada de inapreciables cualidades en cuanto a solidez y economía. La polea "SUBLIME" es susceptible de funcionar sin ruido, libre de accidentes y no altera la disposición del mobiliario.

Con la polea "SUBLIME" se orillan las dificultades consiguientes del gimnasio; los enfermos pueden trabajar desde el lecho y se remite embalada en dos centímetros cúbicos, acompañando cuaderno ilustrado y explicativo del uso y colocación, con especialidad en marcos de puerta.

Como elemento preservativo de padecimientos diversos, es inmejorable. (Martínez Díaz, 1893, p. 1) 


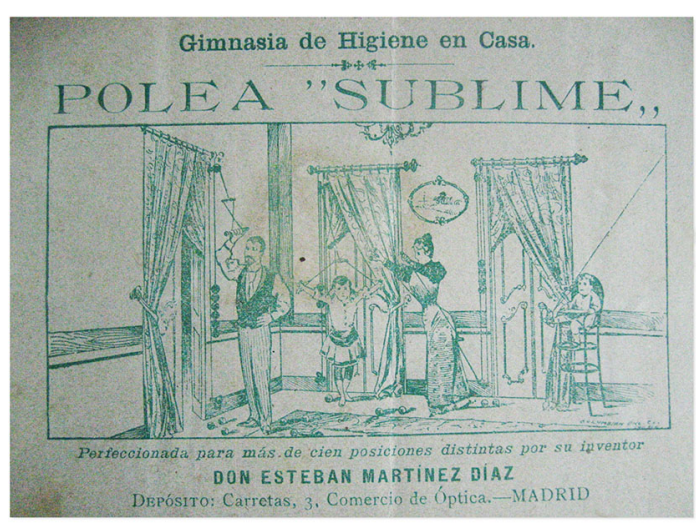

FIGURA 10

Portada manual Polea "Sublime"

Nota: Propiedad particular.

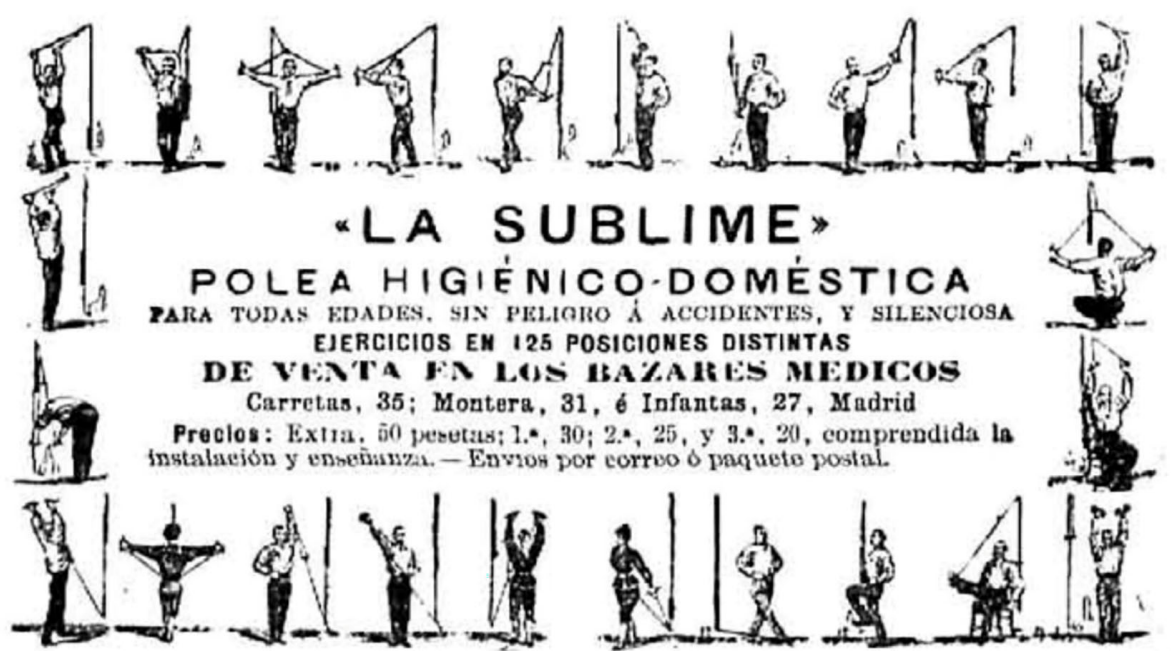

FIGURA 11

La Ilustración Española y Americana, 15 de marzo de 1893, p. 170.

Nota: Disponible en: http://hemerotecadigital.bne.es/issue.vm?id=00011499

79\&page $=14 \&$ search $=$ polea\&lang $=$ ca Colección HBNE: CC-BY-NC-SA 4.0.

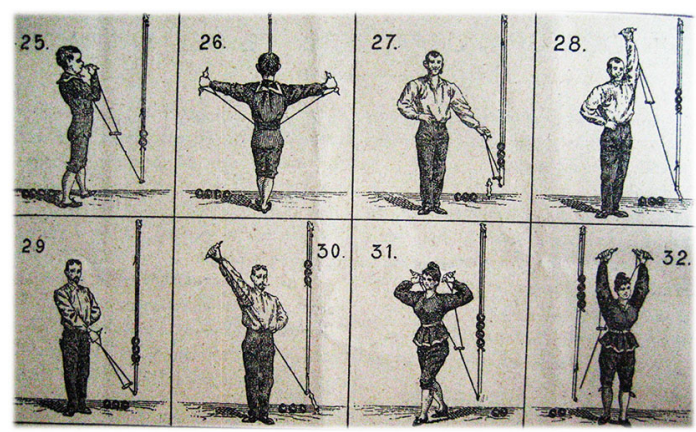

FIGURA 12

Gimnasia higiénico-doméstica. Polea Sublime (Martínez Díaz, ca. 1900).

Nota: Propiedad particular.

Hemos de suponer que este sencillo folleto ilustrado con cuarenta ejercicios de poleas fuese el manual de uso que acompañaba la compra del aparato. Sobre él se citaba que estaba "patentado por 20 años en varias naciones" y se advertía: 
La invención de La Sublime tiene por objeto facilitar el desarrollo de la criatura desde los cinco años en su domicilio, en condiciones perfectas y económicas.

Su mecanismo es sencillo, puede ser colocada en cualquier habitación en breves minutos.

Para la mejor conservación deben aligerarse los pesos una vez terminadas las prácticas, engrasando a menudo las roldabas, con un preparado de sebo y aceite a partes iguales.

Es de suma necesidad consultar con facultativos la índole, peso y duración de los movimientos, para que los resultados sean positivos e inmediatos, en caso de enfermedad.

Este aparato es susceptible a todos los organismos débiles o robustos, a toda clase de movimientos sin peligro de ningún género, y silenciosa su función.

Los enfermos pueden manejarla desde el lecho si fuera preciso. (Martínez Díaz, ca. 1900, interior de la tapa externa)

La publicidad de estos productos contaba con el soporte de la prensa y de algunos artículos del público usuario que tenía a bien publicar la recomendación. No hay duda que esta era una estrategia comercial ingeniada por los mismos sujetos representantes de los aparatos:

Hemos tenido ocasión de ver el aparato de gimnasia inventado por D. Esteban Martínez Díaz. Su autor lo denomina «Polea sublime», y es lo más completo a la par que lo más sencillo y lo más útil que existe en punto a gimnasia higiénico-doméstica.

El Sr. Martínez Díaz se ha propuesto con su admirable invento facilitar el desarrollo de los niños desde los cinco años de edad, en condiciones perfectas y económicas, y en verdad que lo ha conseguido con su precioso aparato gimnástico. Su mecanismo es tan sencillo, que puede ser colocado en cualquier habitación en breves momentos, y su uso tan conveniente, que es aconsejado por los médicos como de necesidad absoluta para la salud y robustez de los niños. No solo éstos, también las personas mayores pueden emplearlo como medio de conservar la salud. (Editorial El País, 1893, p. 2)

En 1893 El Diluvio de Barcelona ${ }^{[3]}$ anunciaba: "Gimnasia higiénica en casa. Polea Sublime sistema Martínez para ambos sexos; instalase en todo domicilio. Libre de accidentes y de completo desarrollo físico... instalación y enseñanza gratis" (Martínez, 1893, p. 60) (Figura 13). Esta polea apareció durante muchos años anunciada en los diarios y revistas (Figura 14).

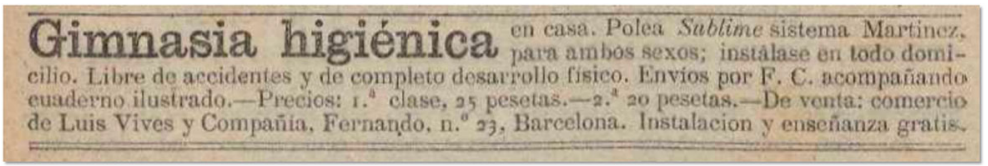

FIGURA 13

El Diluvio: diario político de avisos, noticias y decretos, Barcelona, 3 de enero de 1893, p. 60

Nota: Colección ARCA (https://arca.bnc.cat/arcabib_pro/en/catalogo_imagenes/

grupo.do? path=1371532\&posicion=2\&presentacion=pagina). En Dominio Público.

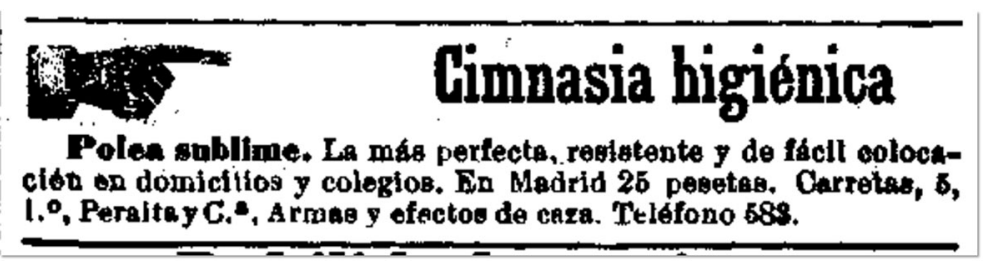

FIGURA 14

Diario Oficial de Avisos de Madrid, 16 de enero de 1895, p. 4

Nota: Colección HBNE (http://hemerotecadigital.bne.es/issue.vm?id=0000639049\&search=\&lang=es). CC-BY-NC-SA 4.0.

En 1893 la prensa de la capital (El Liberal, El Imparcial, La Correspondencia de España) publicitaba:

la polea elástica inglesa de caoutchove es la más higiénica de cuantas se conoce, restituye las fuerzas y desarrolla el pecho en pocos días. Se pueden hacer todos los ejercicios en la propia habitación; es recomendada por todas las eminencias médicas, y de uso en todos los colegios extranjeros. (Figura 15)

En 1894 El Liberal, El País, El Imparcial, La Correspondencia de España y El Heraldo de Madrid, anunciaban la "polea inglesa: Regenera las fuerzas y desarrolla el pecho en pocos días, la más portátil, higiénica y sólida (dos fiadores)" (Gimnasia doméstica, 1893, p. 4; Gimnasia doméstica, 1894, p. 4) (Figuras 16 y 17). 


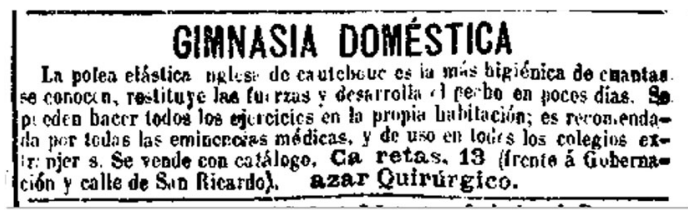

FIGURA 15

La Correspondencia de España, 10 de marzo de 1893, p. 4

Nota: Colección HBNE (http://hemerotecadigital.bne.es/issue.vm?id=0000377453\&search=\&lang=es). CC-BY-NC-SA 4.0.

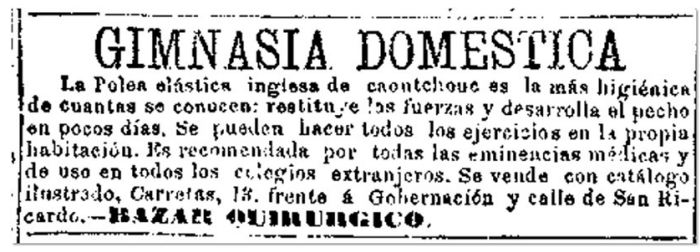

FIGURA 16

El Liberal, 9 de marzo de 1893, p. 4

Fuente: Colección HBNE (http://hemerotecadigital.bne.es/issue.vm?id=0001229441\&search=\&lang=es). CC-BY-NC-SA 4.0.

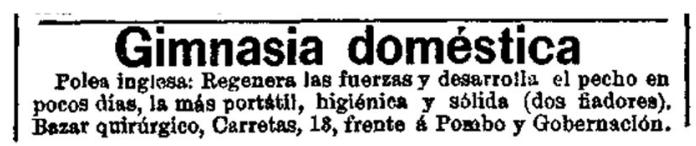

FIGURA 17

El Pais, 17 de marzo de 1894, p. 4

Nota: Colección HBNE (http://hemerotecadigital.bne.es/issue.vm?id=0001766530\&search=\&lang=es). CC-BY-NC-SA 4.0.

Si bien la gimnasia doméstica o "casera" entraba como posibilidad para quienes por cualquier circunstancia no podían o, sencillamente, no deseaban por comodidad o cualquier otra consideración asistir al gimnasio, había la posibilidad de que un profesor o profesora ofreciera las clases particulares a domicilio (Sánchez Somoano, 1883a). De todos modos, aparte de la gimnasia de sala, estos nuevos aparatos más manejables, como las poleas o las simples pesas pequeñas, ofrecían la posibilidad de realizar un ejercicio físico sin riesgo alguno, alejado de embarazosas situaciones, como bien indica la composición humorística "Gimnasia casera" (Figura 18). 


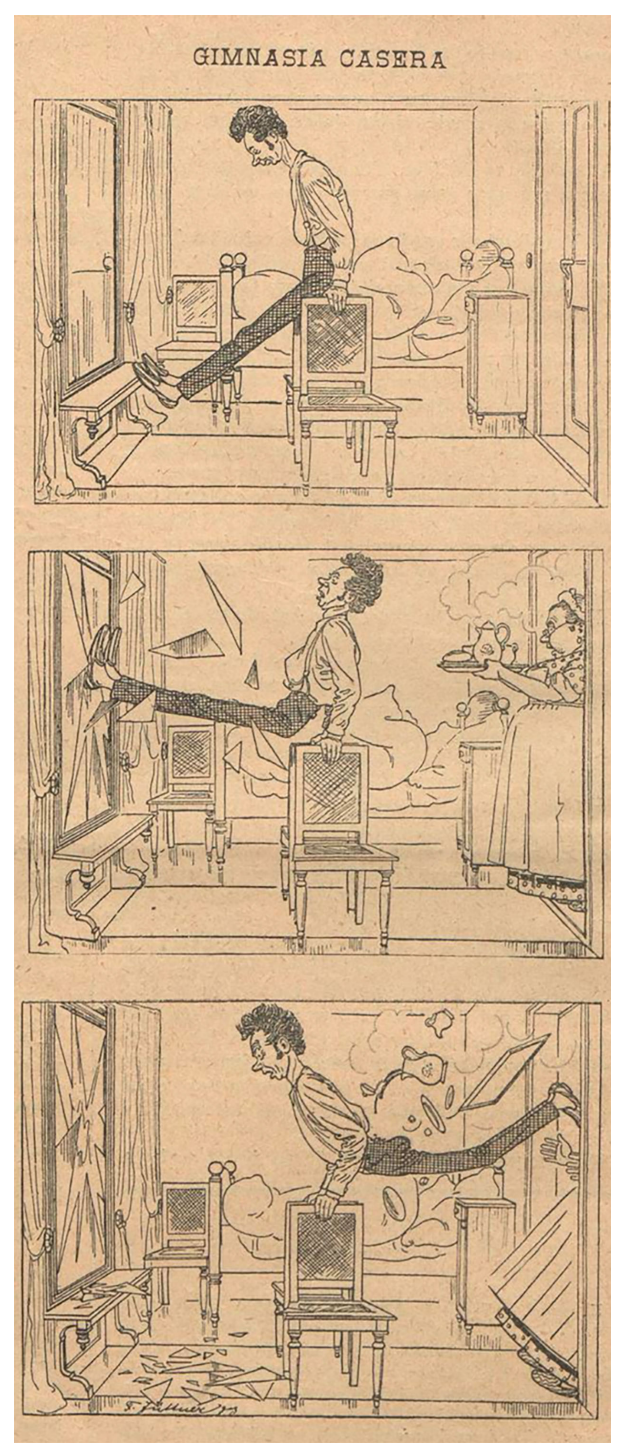

\section{FIGURA 18}

“Composición humorística”, La Hormiga de Oro, 31 de mayo de 1894, p. 318.

Nota: Colección HBNE (http://hemerotecadigital.bne.es/issue.vm?id=0012084021\&search=\&lang=es). CC-BY-NC-SA 4.0.

A comienzos del siglo pasado la "gimnasia doméstica" entró en una mayor visibilidad publicitaria. El Dr. E. Cleriot, uno de los principales representantes de la gimnástica sueca en Madrid, presentó uno de los aparatos gimnásticos que más se difundieron a lo largo de todo el siglo, la "polea universal". Aunque el autor recomendase la polea para todo tipo de establecimientos y de gimnásticas, el genuino sistema era la concepción más moderna del "gimnasio en casa". La obra presenta 18 ejercicios, con ilustraciones, que atendían la posición inicial, el movimiento desarrollado y los efectos producidos (Figura 19).

Si bien tenemos apenas datos del autor, conocemos que fue miembro de la Sociedad Gimnástica Española y que publicó varios artículos en la Educación Física Nacional (1902).

En cuanto a la polea universal, es por decirlo así, una pequeña enciclopedia de los movimientos gimnásticos; representa la más económica y completa instalación gimnástica de sala; de gran facilidad en el manejo, sin exposición alguna, reúne a las anteriores condiciones otras de gran valor: da fuerza y vigor, y cierta elegancia cuando se ejecutan bien sus diversas y numerosas aplicaciones; sirven unas para gimnasia higiénica, para la pedagógica o educativa otras, y por último para la terapéutica las restantes; por tales razones, este precioso aparato no debe de faltar en casa, en la escuela, en el colegio y en los hospitales y en los sanatorios. (Cleriot, 1900, pp. 6-7) 

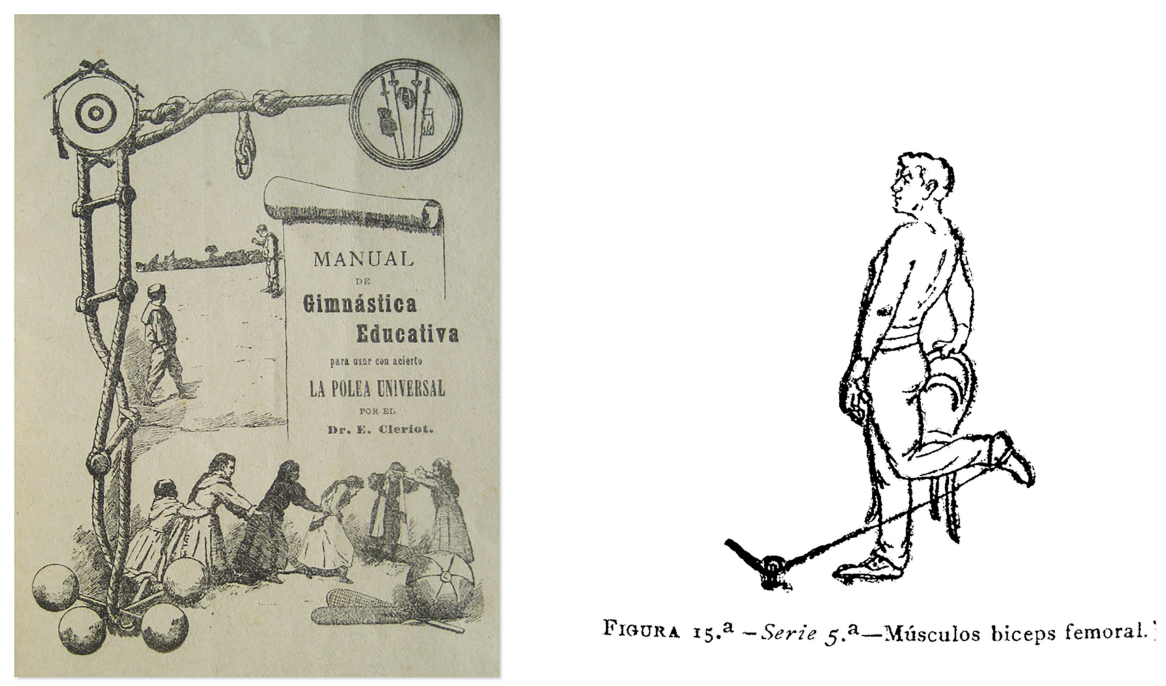

FIGURA 19

Portada y ejercicio del Manual de gimnástica higiénicoeducativa: para usar con acierto la Polea Universal (Cleriot, 1900)

Nota: Propiedad particular.

La "Polea Universal" fue expuesta como un medio higiénico de gimnástica; puesto que evitaba todo ejercicio violento, además de facilitar el trabajo equilibrado y completo de todos los grupos musculares.

Los ejercicios en este nuevo aparato no son, ni pueden ser, porque no lo permite, ni acrobáticos, ni violentos; son, por el contrario, lentos, uniformes y sin grandes esfuerzos, y permiten que el músculo se nutra cuando se contrae por la acción del ejercicio gimnástico.

Por eso el ejercicio con la polea universal concede a nuestro organismo armonía y elegancia en la forma, fuerza, resistencia y elasticidad al músculo y a las articulaciones, con un ejercicio diario y racionalmente practicado... (Cleriot, 1900, p. 8)

En La Educación Física Nacional, Cleriot (1901) fue uno de los primeros en divulgar en España el método de gimnasia sueca. Esto sucedía cuando en esta misma revista, aparte de la "Polea Universal", igualmente se anunciaban las pesas con resortes y la polea Sandow.

También fue conocida la "polea gentil gradual" que se podía conseguir al precio de 35 pesetas. En el prospecto comercial de esta polea, con ejemplo de 14 ejercicios, se citaba [Figura 20]:

Es la más eficaz conocida para reconstituir las fuerzas, exterminar la anemia, raquitismo, debilidad general y obtener buen apetito.

El ejercicio es uno de los principales elementos prescrito por los higienistas. Así, pues, con este aparato sencillísimo según opinión facultativa, se consigue rápidamente la regeneración, fuerza y desarrollo del pecho, brazos, riñones, piernas, y en general de todos los miembros humanos debilitados, siendo eficacísimos sus efectos para corregir la deformidad de los huesos producida por la debilidad de los mismos, de que tantos casos se ven, especialmente en los niños. (Polea gentil gradual, 1900, p. 1) 


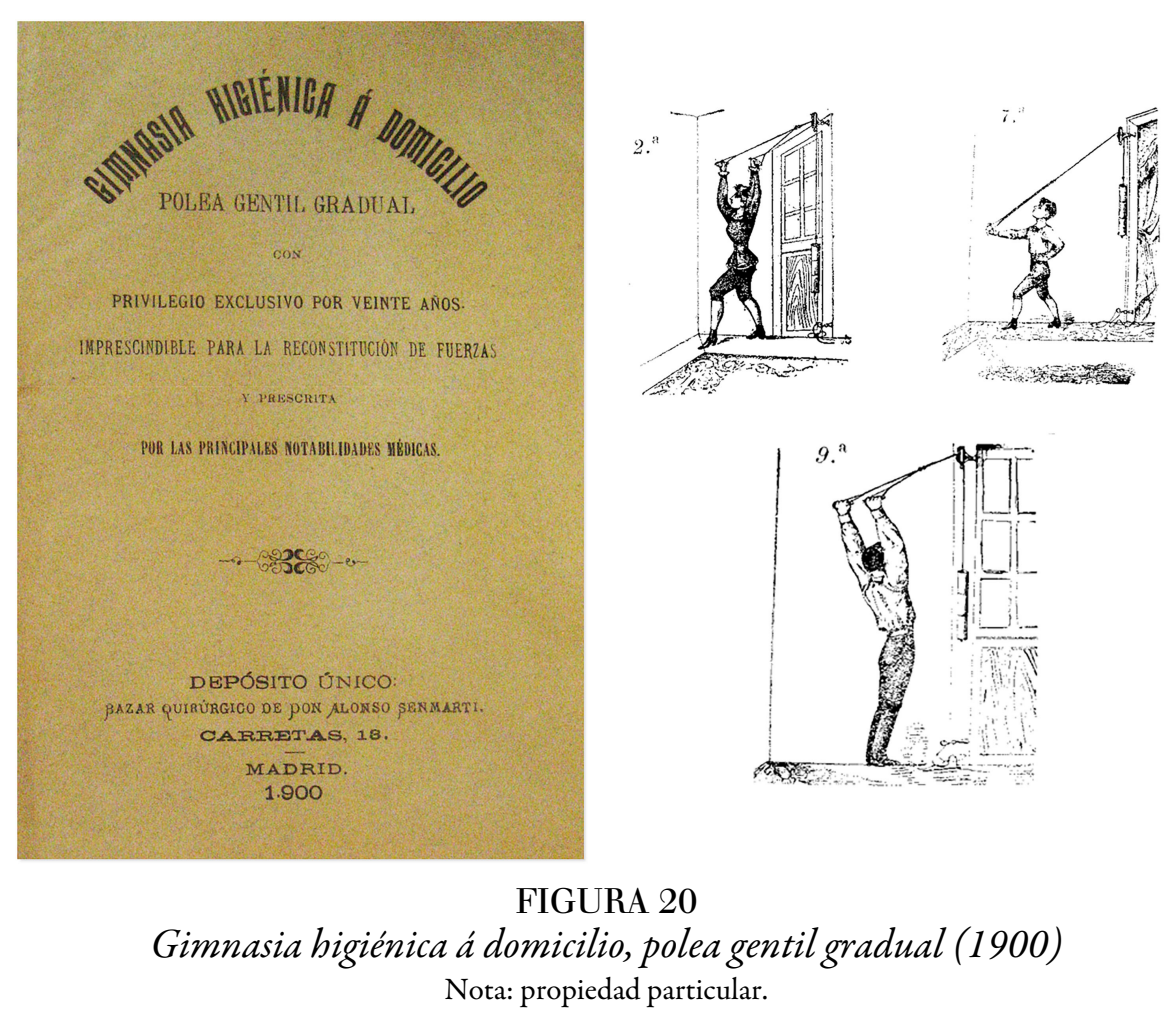

El doctor David Ferrer (1900) en Los Deportes -la revista de educación física y de deportes más importante de España (1897-1910) - se ocupaba de los avances de la gimnasia moderna. Mencionaba que la gimnasia en casa se había desarrollado muchísimo en el extranjero y, particularmente, en América del Norte. Entre los modernos aparatos destacaba los cables de goma elástica Whitely (figura 21).
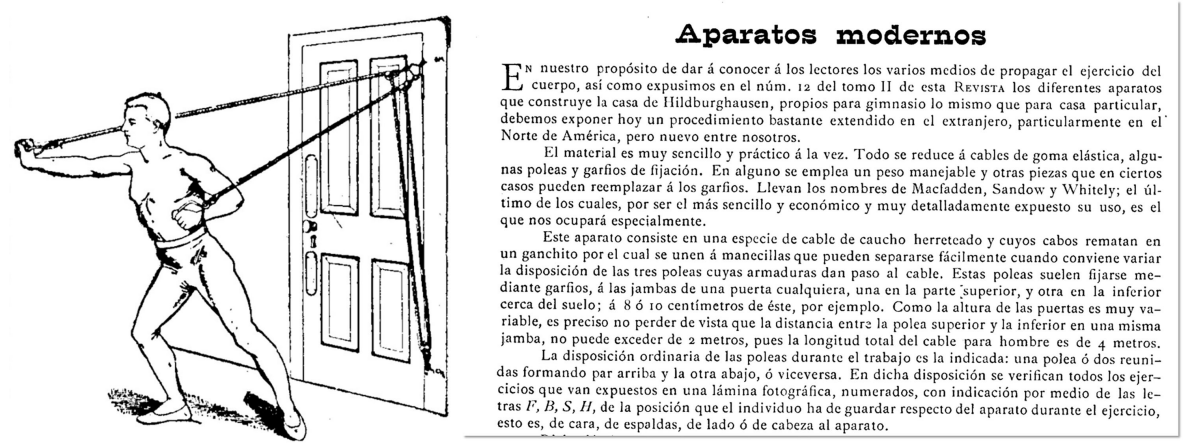

FIGURA 21

"Polea Sandow-Withely" "Aparatos modernos"

Nota: Los Deportes, Revista Semanal Ilustrada, 21 de enero de 1900, pp. 36-37. Colección ARCA ( https://arca.bnc.cat/arcabib_ pro/en/catalogo_imagenes/grupo.do?path=1023389\&posicion=1\#search=\%22aparatos+modernos\%22). En Dominio Público

En cuanto a la mujer, la gimnástica doméstica ofrecía algunas ventajas. Primeramente, debemos considerar la educación burguesa y victoriana de muchas de las mujeres, ya fueran jóvenes chicas o mujeres casadas y de edad avanzada. Estas casi siempre estaban confinadas a los espacios cerrados. Con los nuevos aparatos no tenían que exponer su pudor en público. Pero la más importante de las ventajas era que se podían ejercitar libremente. Ya hemos visto que uno de los métodos fue el de la gimnasia de sala y, desde 1861, aparte del Manual de Schreber (1864), prácticamente, no se publicaron manuales de gimnástica para la mujer hasta que en 1903 apareció una obrita de Julián de las Barreras (Torrebadella, 2011). No obstante, como trata Pastor 
(2003, p. 191), la gimnástica de la mujer estuvo sujeta a tres condicionantes: "la feminidad, la maternidad y la sexualidad".

En Los ejercicios gimnásticos en el bello sexo (1903), el profesor De las Barreras, titulado en la Escuela Central de Gimnástica, indicaba el escaso número de profesionales con preocupación por la educación física de la mujer, pero cuyas propuestas solamente se remitían a simples aportaciones teóricas citadas en artículos periodísticos y en conferencias. A estas observaciones, se unía el poco interés por la educación física del "bello sexo". El autor consideraba la educación física de la mujer como uno de los objetivos más importantes para la regeneración física; era tan importante el vigor físico de la mujer que, de no tenerlo, podía suponer la decadencia del Estado. Se decía que la mujer necesitaba realizar ejercicios activos (marcha, baile, equitación y natación), además de ejercicios gimnásticos que vivificaran su organismo y la alejaran del sedentarismo, del raquitismo y de la histeria. De las Barreras consideraba que los ejercicios gimnásticos para la mujer debían ser moderadamente enérgicos, agradables y de efecto general.

Esta sencilla obra puede ser calificada como la primera obra autóctona de gimnástica de aplicación práctica del siglo XX dirigida exclusivamente al sexo femenino:

En tan lamentable estado de descuido se halla la práctica de ejercicios gimnásticos por la mujer, que es un hecho admitido que nadie se ocupa de pensar en ellos y muchos están lejos de considerarlos como uno de los puntos esenciales en la educación del bello sexo. (De las Barreras, 1903, p. 7)

Efectivamente, la gimnasia doméstica tenía entre los principales beneficiarios a la población femenina. Como indicaba Anadeo Llaverías, erudito conocedor de la gimnástica en Barcelona, ya se hacía notar el progreso de la cultura física -la gimnástica y los deportes- entre el llamado "bello sexo" que, aparte de ir al gimnasio y de practicar deportes como el patinaje o el tenis, también se ejercita "en sus propios domicilios a expensas de la polea Whitely, los aparatos Sandow y otros, cuya continuada demanda rinde pingües beneficios a buen número de comercios" (Llaverías, 1904, p. 684).

Además, observamos que, a principios del siglo XX, la cultura física entró en las clases medias y, aparte del uso de aparatos domésticos, el soporte de manuales de ejercicios favoreció el espacio propagandístico de la gimnástica. Con la proliferación de los manuales de gimnástica doméstica se proyectó una cultura física al alcance de todas las personas, es decir, al margen también del gimnasio y, por lo tanto, sin la necesidad de disponer de una dirección técnica. Al respecto puede afirmarse que en la gimnasia sueca se encontraban las bases para legitimar el ejercicio físico entre las clases medias (Kumlien y Andre, 1904; Kumlien, 1907; Romero 1905; Soleirol y Le Roux, 1906) (Figura 22). 

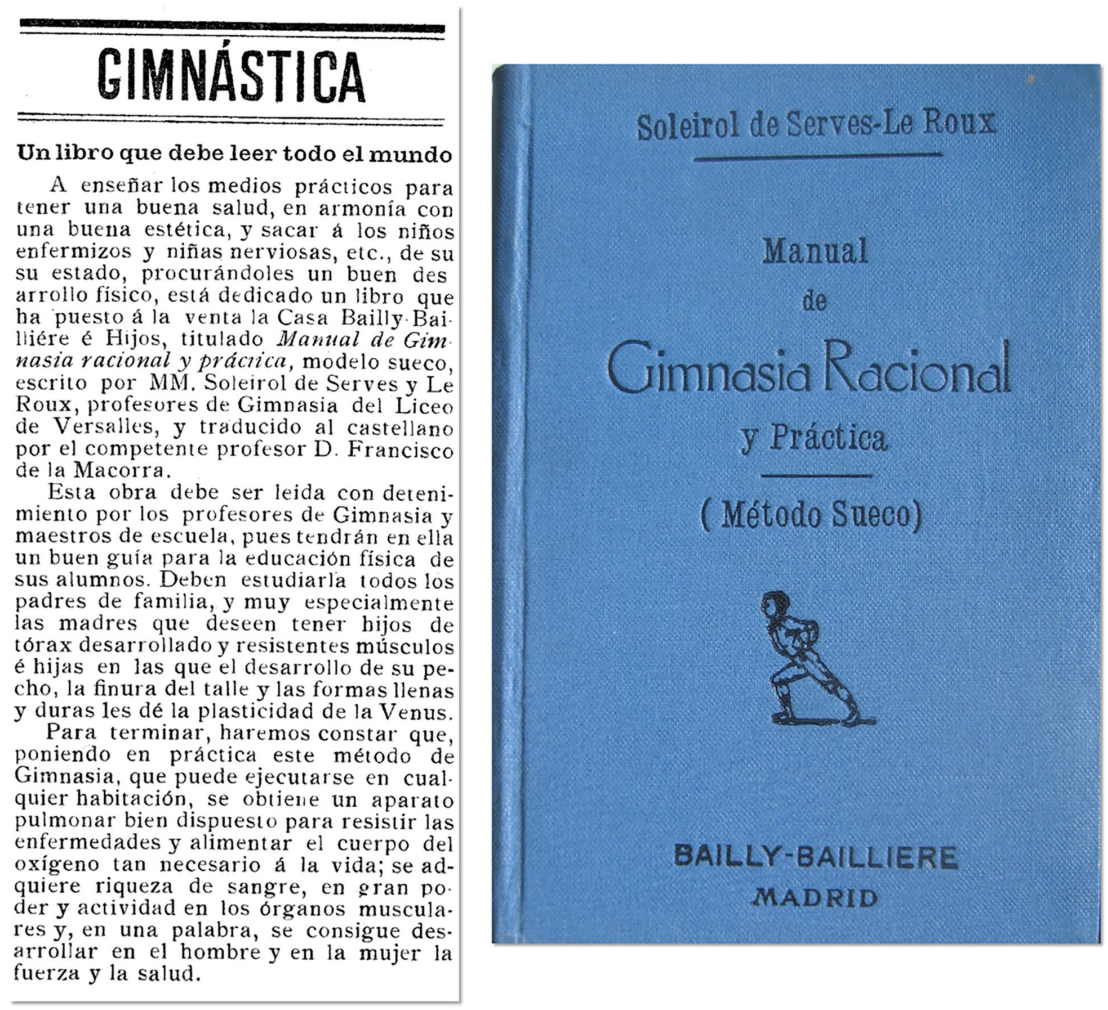

\section{FIGURA 22}

El Mundo Deportivo, 13 de diciembre de 1906. Fuente: Hemeroteca de El Mundo Deportivo. Portada libro Manual de Gimnasia racional (1906)

Nota: Propiedad particular

A principios del siglo XX, la prensa barcelonesa (La Publicidad y La Veu de Cataluña) comenzó a publicitar los productos gimnásticos de Eugenio Sandow: las pesas con resortes Sandow y la polea-tensor Sandow.

Eugenio Sandow (1867-1925) fue un atleta de origen prusiano que está considerado entre los pioneros del culturismo moderno, es decir, se dice que fue el primer hombre que empezó a ganar dinero y fama internacional exhibiendo la estética hercúlea de su cuerpo (Chapman, 1994; Waller, 2011). En España, una de las primeras noticias de Sandow (1892) apareció en La Ilustración Artística, y luego, en pocos años, sus métodos de educación física fueron conocidos por todo el mundo y sus proezas hercúleas llenaron las páginas de las revistas gráficas.

Si bien el 10 de octubre de 1905 Sandow -llamado el "Rey del Atletismo"- tuvo dedicada la portada de Los Deportes y una breve reseña alegórica: "Su corpulencia y fuerza son extraordinarias, ... todo ello obtenido con su perfecto método y aparatos sencillísimos que se venden hoy en todas partes" (Sandow, 1905, p. 370); un mes más tarde, Sandow era considerado responsable del mercantilismo de la cultura física (Morais, 2013):

Mercantilismo de fin de siglo.... Iniciador míster Sandow (cuyo talento comercial supera todavía yen mucho á su portentoso vigor) de un mercado tan nuevo como lucrativo, puesto que usando y abusando de la fama adquirida como atleta profesional en sus constantes exhibiciones en circos y teatros de las mejores capitales del mundo, le ha servido para sacar gran provecho al proclamarse de su mutuo propio regenerador de la raza actual. Al efecto, provisto del citado título que graciosamente se adjudicara, empezó por inventar poleas, pesos, aguas para dar fricciones, etcétera; escribió libros, publica revistas y no sabemos si andando el tiempo inventará alguna pomada para el cabello, ó bien calzoncillos higiénicos, pues todo producto, con llevar su nombre es ya garantía para adquirir súbitamente, una fuerza semejante á la suya, y por ende, poder presumir. (Palomo, 1905, p. 730) 
Los productos de Sandow fueron divulgados por toda España: "Sandow's el aparato más sencillo y completo de gimnástica doméstica que se conoce hasta el día” (Molina, 1900, p. 4). Asimismo, los gimnasios también se proveían de estos aparatos, como así lo hizo en Murcia el Gimnasio Modelo de Francisco Medel que, entre los aparatos modernos, incorporó las poleas de Whitely y de Sandow, haciéndose cargo de la representación en Murcia de estas marcas (Medel, 1900) (Figura 23)

\section{Noticias Locales}

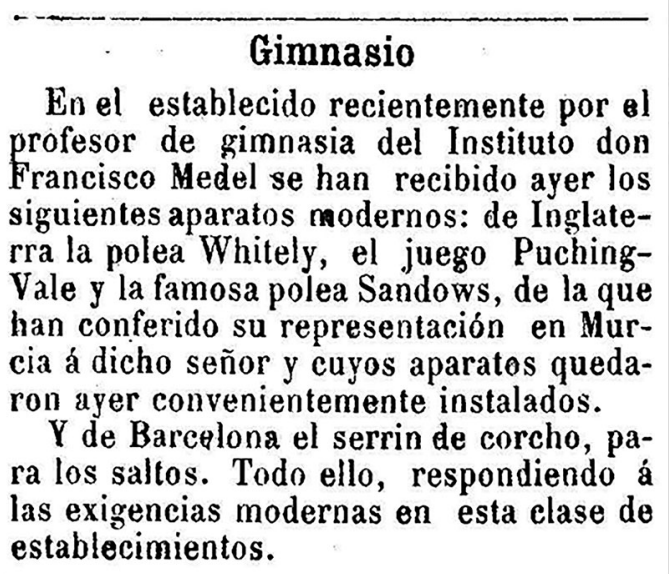

FIGURA 23

Diario de Murcia, 22 de noviembre de 1900, p. 3

Nota: Colección Archivo Municipal de Murcia (https://www.archivodemurcia.es/p_pandora4/view er.vm $? \mathrm{id}=0000160505 \&$ page $=3 \&$ search $=$ gimnasio\&lang=es\&view=hemeroteca). Dominio Público.

Las pesas con resortes Sandow consisten en unas mancuernas destinadas a niños, niñas, mujeres y gente mayor, con escasa fuerza y con necesidad de ejercicio. Los resortes incorporados a las pesas tenían el objetivo de facilitar una compresión de la mano mientras se ejecutaban los distintos movimientos, con lo cual aumentaba la tensión y la fuerza aplicada. Naturalmente, había una graduación de pesos: $1360 \mathrm{Kg}$ para hombres, $900 \mathrm{Kg}$ para señoras y jóvenes, 600 gramos para señoritas y adolescentes; y $300 \mathrm{Kg}$ para niñez (Figura 24). Estas originales pesas fueron muy publicitadas en los diarios y las revistas (Figura 25 y 26 ). 


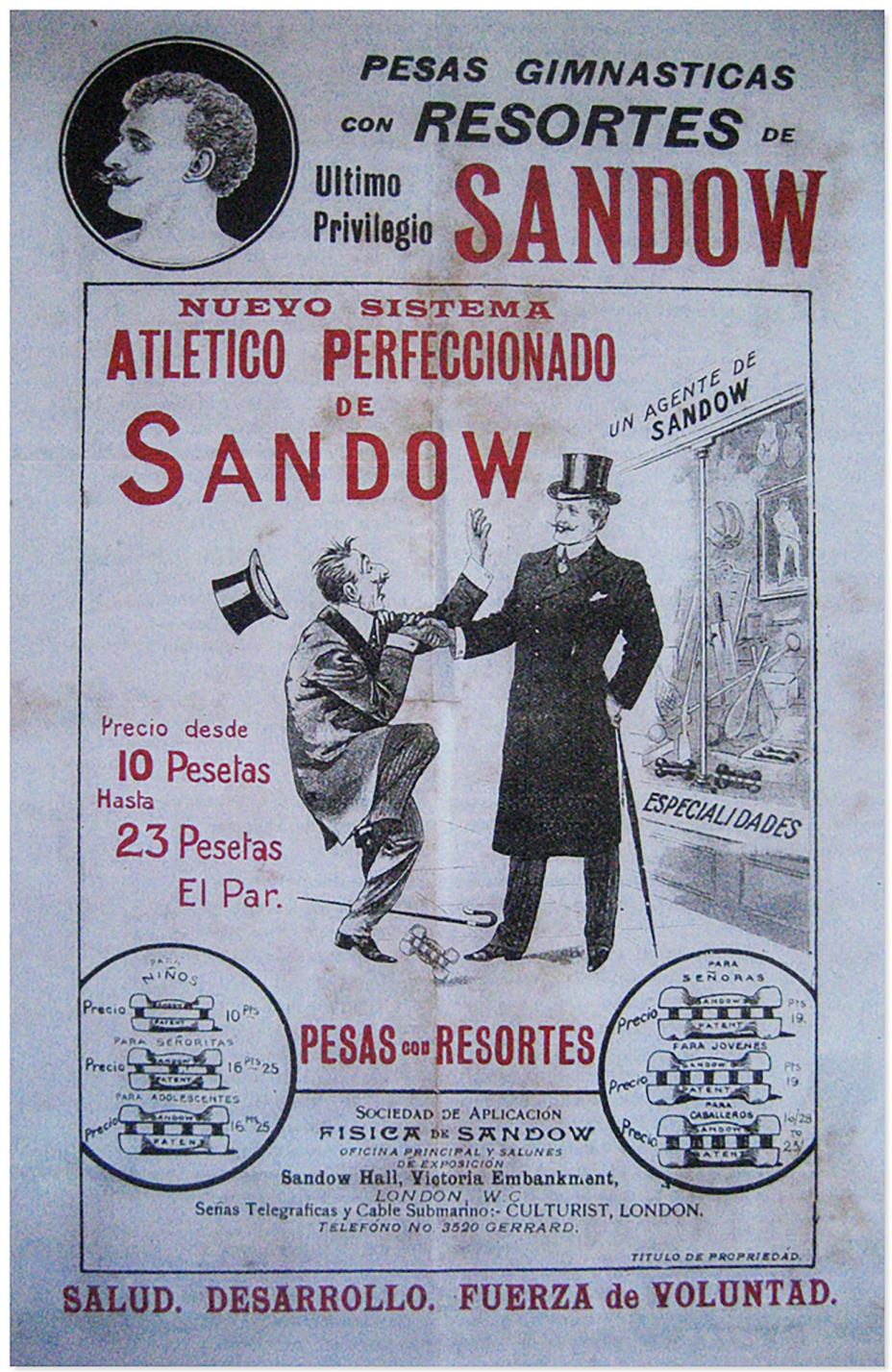

FIGURA 24

Portada prospecto publicitario

Nota: Propiedad particular.

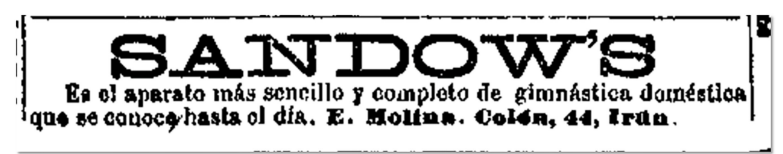

EL SANBOW'S es el aparato de gimnistica domérlica, Doposi. tario Lspania. E, atelans.

\section{FIGURA 25}

El Liberal, 11 de enero de 1900, p. 4; 15 de septiembre de 1900, p. 4

Nota: Colección HBNE (http://hemerotecadigital.bne.es/issue.vm?id=0001341356\&search=\&lang=es). CC-BY-NC-SA 4.0. 

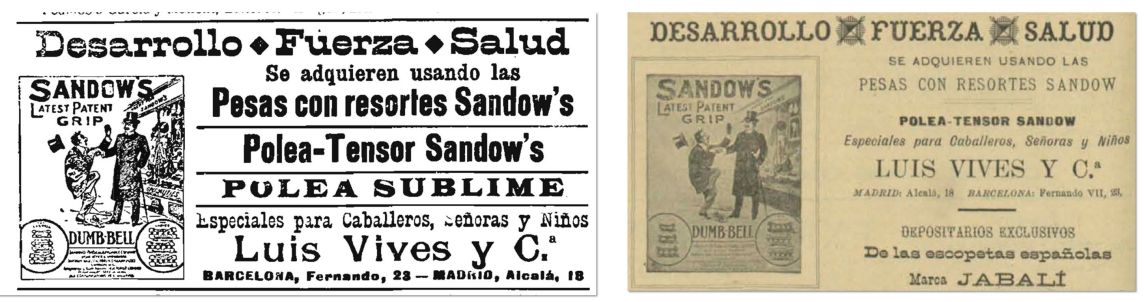

FIGURA 26

La Publicidad (Edición de la noche), Barcelona, 27 de diciembre de 1900, p. 1; Gente Vieja, Madrid 10 de mayo de 1901, p. 12

Nota: Colección ARCA (https://arca.bnc.cat/arcabib_pro/en/catalogo_imagenes/grupo.do?path=1426209), En Dominio Público y Colección HBNE (http://hemerotecadigital.bne.es/issue.vm?id=0005190398\&search=\&lang=es). CC-BY-NC-SA 4.0.

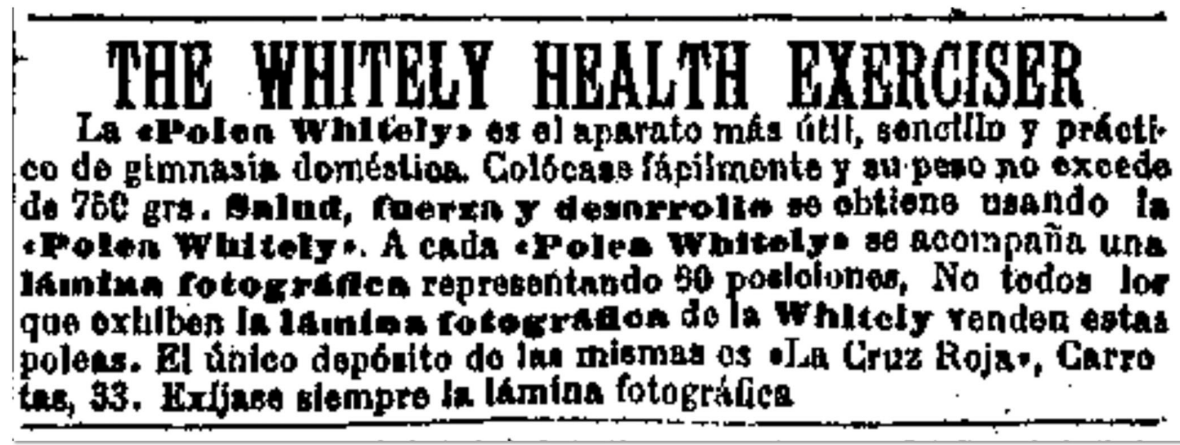

FIGURA 27

El Liberal, 11 de marzo de 1901, p. 4.

Nota: Colección HBNE (http://hemerotecadigital.bne.es/issue.vm?id=0001352351\&search=\&lang=es). CC-BY-NC-SA 4.0.

Otro conocido sistema de polea, pero no muy divulgado, fue la polea de Alexander Whitely creada en 1894 (Figura 27):

es el aparato más útil, sencillo y práctico de la gimnasia doméstica. Colocase fácilmente y su peso no excede de 750 grs. Salud, fuerza y desarrollo se obtiene usando la "Polea Whitely". A cada "Polea Whitely" se acompaña una lámina fotográfica representando 50 posiciones. No todos los que exhiben la lámina fotográfica de Whitely venden estas poleas. (Whitely, 1901, p. 4).

En 1897 Withely se unió con Sandow para promocionar su polea, pero este último perfeccionó el sistema al unificar la polea con pesos extraíbles, y su asociación quedó disuelta, con lo que el aparato inicial de Withely quedó en desuso (Morais, 2013; Waller, 2011).

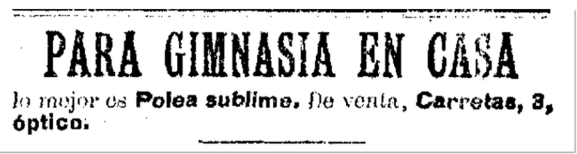

GIMNASIA PERFEGTA. POLEA \&SUBLIME* colocada y con instrucción á domicilio, 25 pese. tas. Véndese Carretas, 3. Optico.

FIGURA 28

La Época, 18 de mayo de 1904, p. 3; El Imparcial, 20 de diciembre de 1904, p. 4 Nota: Colección HBNE (La Época: http://hemerotecadigital.bne.es/issue.vm?id=0000702081\&search=\&lang=es y El Imparcial: http://hemerotecadigital.bne.es/issue.vm?id=0000866561\&search=\&lang=es). CC-BY-NC-SA. 4.0. 


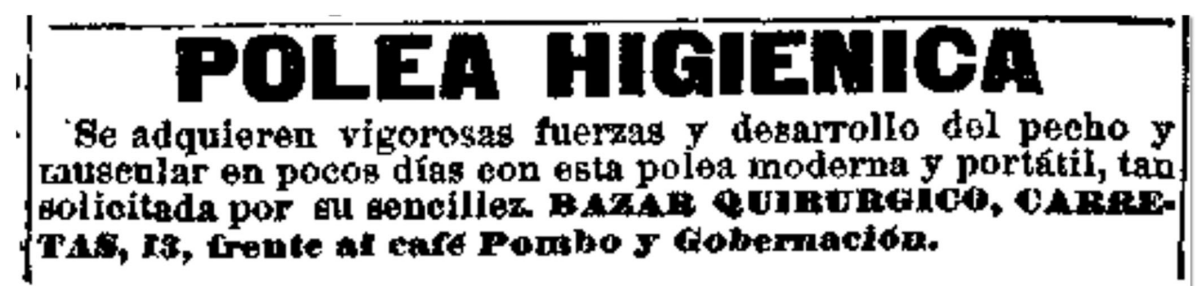

FIGURA 29

Heraldo de Madrid, 7 de noviembre de 1904, p. 4

Nota: Colección HBNE (http://hemerotecadigital.bne.es/issue.vm?id $=0000505862 \&$ page $=4 \&$ search $=$ polea\&lang $=$ ca).. CC-BY-NC-SA 4.0 .

De todos modos, seguían comercializándose otras poleas como la Polea "sublime" (1904, p. 4), que se publicitada como la "gimnasia perfecta" y se vendía colocada a domicilio y con instrucciones; también aparecía "para la gimnasia en casa la mejor es "Polea sublime" (1904, p. 4) (Figura 28). Otra fue la "Polea higiénica” (1904, p.4), con la cual "se adquieren vigorosas fuerzas y desarrollo del pecho y muscular, en pocos días, con esta polea moderna y portátil, tan solicitada” (Figura 29).
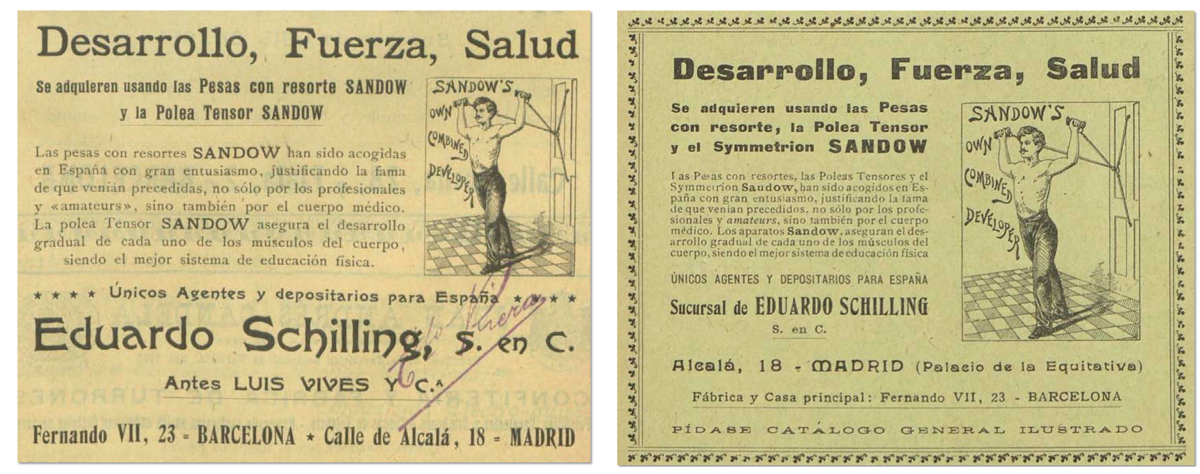

FIGURA 30

Anuario Riera, Barcelona, 1904; Directorio madrileño, p.744 (publicado por el Anuario Riera), 1905 Nota: Colección HBNE, CC-BY-NC-SA 4.0.

La Sociedad de Eduardo Schilling (1852-1925) - de Barcelona y con sucursal en Madrid- se presentaba como el único agente comercial y depositario para España de los productos Sandow (Figuras 30 y 31):

Las pesas con resortes SANDOW han sido acogidas en España con gran entusiasmo, justificando la fama de que vienen precedidas, no solo por los profesionales y “amateurs", sino también por el cuerpo médico. La polea Tensor SANDOW asegura el desarrollo gradual de cada uno de los músculos del cuerpo, siendo el mejor sistema de educación física. (Anuario Riera, 1904, 1905) 


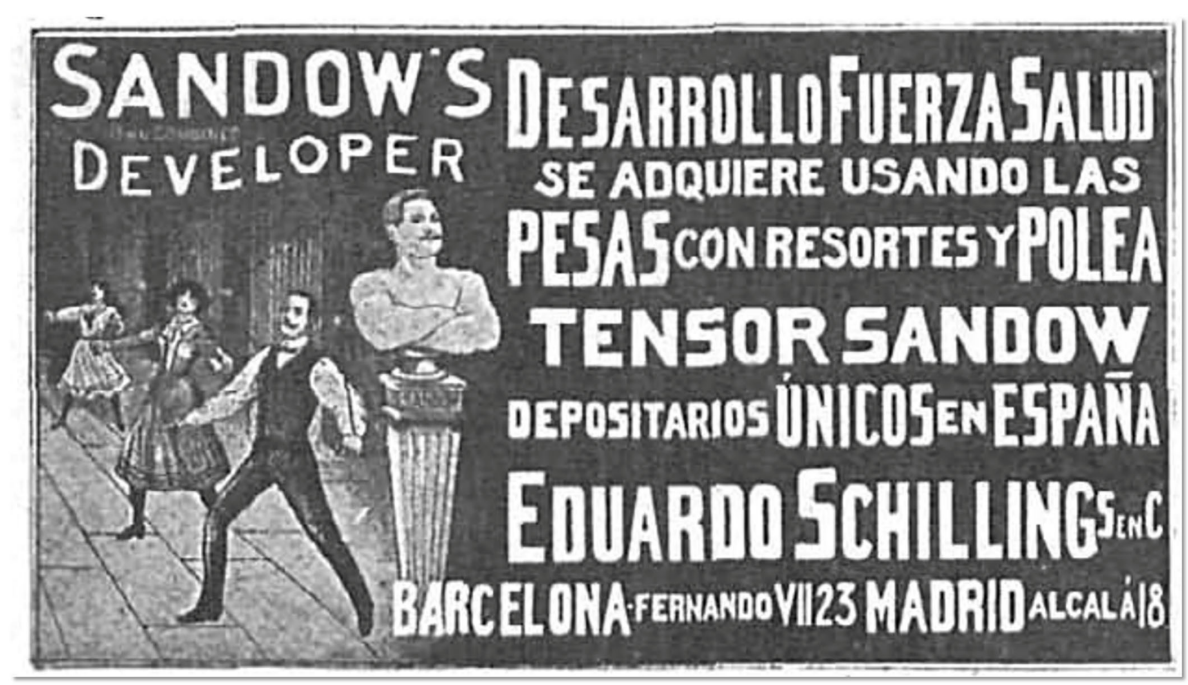

FIGURA 31

Nuevo Mundo, 19 de enero de 1905, p. 24

Nota: Colección HBNE (http://hemerotecadigital.bne.es/issue.vm?id=0001310141\&search=\&lang=es), CC-BY-NC-SA 4.0.

El Dr. E. Cleriot continuaba divulgando las ventajas del ejercicio físico y de cómo se podía conseguir una cierta calidad de vida sin la necesidad de asistir al gimnasio y sin ponerse en las manos de especialistas. A propósito, recomendaba el método del profesor Louis Attila (Ludwig Durlacher, 1844-1924):

A todo el que se ejercite físicamente, hace falta un profesor. Pero desgraciadamente todas las personas no tienen los medios ni se hallan, como antes decimos, en condiciones de poder asistir a las lecciones de un gimnasio.

Menos todavía de llevar un profesor a su domicilio, lo que les imposibilita confiar la educación física de sus hijos a persona competente; más también hay muchos casos en que lo que falta son establecimientos de cultura física y personal técnico. Estas faltas son las que podemos suplir cuanto es posible, porque todas las personas de vida sedentaria y los jóvenes pueden ejercitar sus músculos en su propia casa con gran provecho por medio del método de preparación física del profesor yankee Atila (por nosotros adaptado a las necesidades de la raza latina). (Cleriot, 1905, p. 2)

En definitiva, hay que reconocer que la industria gimnástica ingenió aparatos para facilitar el ejercicio, no obstante, la solución podía encontrarse en una simple silla o en la divulgación más popular de la gimnástica librada de todo cientifismo y sofisticación técnica; dicho de otro modo, se trataba de regresar al sentido común (Figura 32):

Es un error muy generalizado pensar que para hacer gimnasia se necesitan aparatos, o por lo menos una polea o unas pesas. La verdad es que cualquier objeto sirve para el caso; por ejemplo, una silla fuerte, una silla de cocina, constituye un aparato de primer orden, y ofrece ventajas que difícilmente se encuentran en otro cualquiera. Cualquier ejercicio que estire los músculos hace infaliblemente que éstos se desarrollen, siempre que se tenga constancia en practicarlo. (Alhama, 1903, p. 137) 

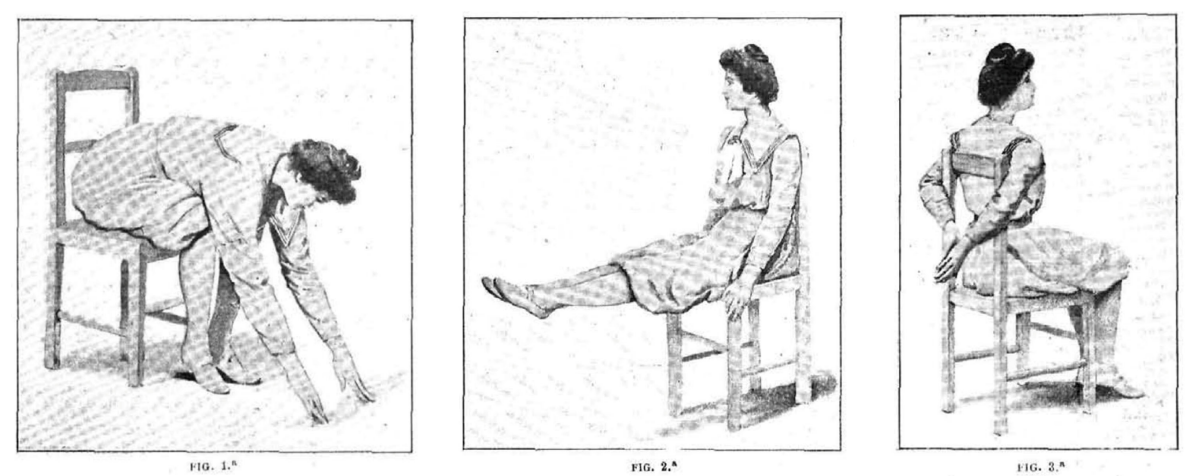

FIGURA 32

“Gimnasia con una silla de cocina”, Alrededor del Mundo, 1903, 27 de agosto, p. 137

Nota: Colección HBNE (http://hemerotecadigital.bne.es/issue.vm?id=0001828767), CC-BY-NC-SA 4.0.

Aun así, la industria gimnástica continuó ingeniando aparatos, ofreciendo soluciones económicas para facilitar el ejercicio físico. En este paradigma, imaginación, ciencia y tecnología se habían puesto en marcha para hacernos una vida más placentera y saludable (Figura 33 y 34 ).

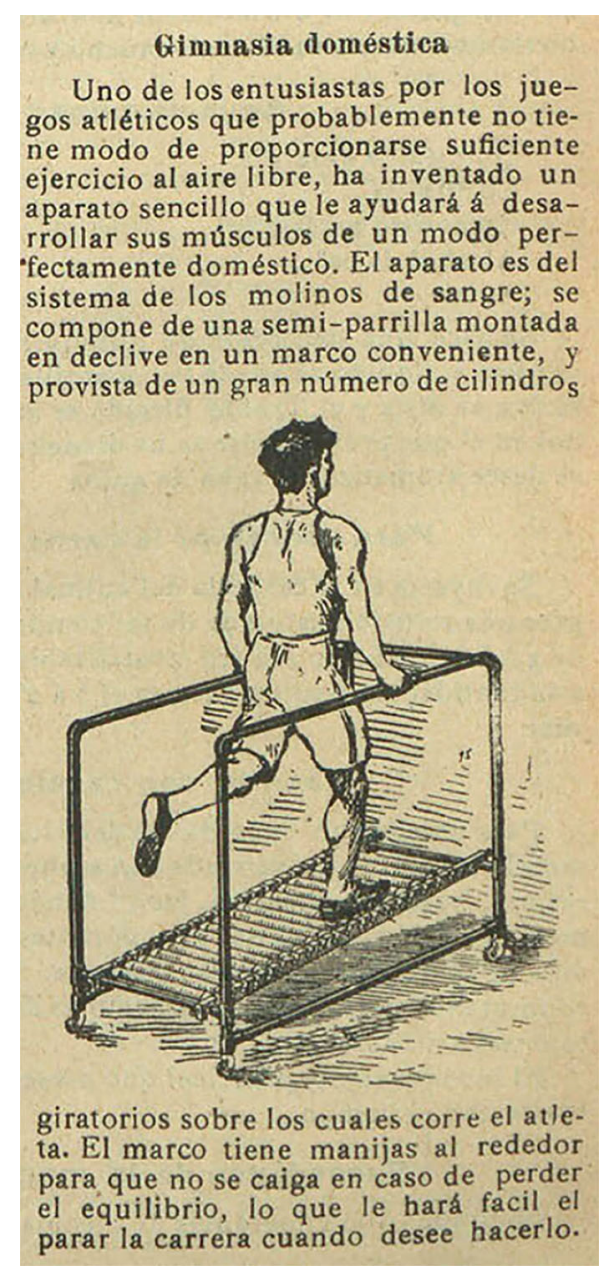

FIGURA 33

El Mundo Cientifico, Barcelona, 20 de noviembre de 1909, p. 585

Nota: Colección HBNE (http://hemerotecadigital.bne.es/issue.vm?id=0026390834\&search=\&lang=es), CC-BY-NC-SA 4.0. 


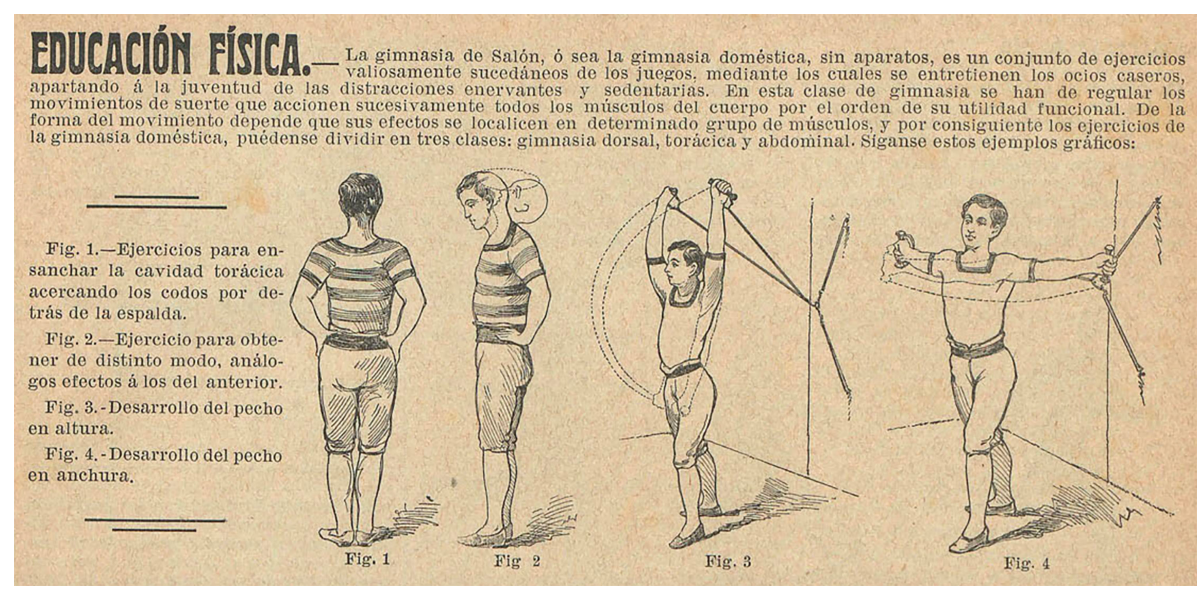

FIGURA 34

Mi revista, Barcelona, vol. 1, 1911, p. 3

Nota: Colección HBNE (http://hemerotecadigital.bne.es/issue.vm?id=0026653190\&search=\&lang=es). CC-BY-NC-SA 4.0.

Como hemos dicho, el método sueco fue tomando asiento cada vez más en el corpus doctrinal de la profesión gimnástica. En España, la gran mayoría de personal médico, militar, docente y profesorado de gimnástica -siempre hay excepciones- se había autoconvencido de que la mejor gimnasia racional e higiénica era el método sueco. El punto de inflexión fue el año de 1912. En primer lugar, apareció Salud, fuerza y belleza por medio de la gimnasia sueca del Dr. Saimbraum (1912) -seudónimo del pedagogo catalán Joan Bardina Castarà (1877-1950) - que puso en el mercado la obra más comercial de la bibliografía de la gimnástica española (Torrebadella, 2011). En segundo lugar, está la consagración internacional de la gimnasia sueca a partir de la significativa repercusión que tuvo en los JJOO de Estocolmo 1912, en los que España no participó.

\section{ConcLuSIONES}

Con este estudio preliminar sobre los comienzos de la gimnasia doméstica, analizando los discursos, los métodos y los instrumentos utilizados, hemos podido ver ciertas singularidades de la implantación en España de la cultura física. Si bien se percibe la impresión de que generalmente la publicidad de la época presentó la cuestión de la mejora de la salud en el campo individual y privado de las personas, en muchas ocasiones los discursos se envolvieron de credos moralizadores y regeneracionistas, es decir, estuvieron centrados en la mejora de la "raza española". Ahora bien, en el fondo de la cuestión subyacían realidades difíciles de encajar. En cultura física, España estaba a la zaga de los países de su entorno; ni se impartía la educación física que debería hacerse en los institutos, ni en la instrucción primaria esta materia se tomaba en serio; no había campos de juego, ni los espacios adecuados para la enseñanza. Los gimnasios privados eran eso, demasiado privados, y solamente unas pocas personas accedían a ellos. Por su parte, los gobiernos solamente se preocupaban por aquellos asuntos en los que, a título individual, podían hacerse más ricos. La regeneración de España fue una completa farsa y la gimnasia sueca, que nacía alimentada en el caudal del regeneracionismo, fue el mayor fraude de la educación física contemporánea, pero de este asunto ya nos ocuparemos en otra ocasión.

Para terminar, hay que reconocer que la gimnasia doméstica sigue su transformación amoldándose a los nuevos tiempos; la constante renovación de ingeniosos utensilios, aparatos y rutinas de fitness se combina con las nuevas tecnologías que logran una sofisticación utilitaria y tentadora del ejercicio físico. Recientemente este escenario se ha visibilizado significativamente ante la pandemia Covid 19, y el forzado confinamiento hogareño de una gran parte de la población ha fortalecido aquel antiguo paradigma que anunciaba las saludables ventajas de la gimnasia higiénica. 
MHSALUd, ISSN: 1659-097X, 18(1), ENERo-Junio, 2021, PP 1-30

TORREBADELLA-FLIX

\section{REFERENCIAS}

Alhama, M. (1903, 27 de agosto). Gimnasia con una silla de cocina. Alrededor del Mundo (Madrid), pp. 137-138.

Anónimo (ca. 1885). Manual práctico de gimnasia de jardín y salón. La bigiene por medio de los ejercicios razonados sin necesidad de aparato. Salvador Manero.

Anónimo X. (1891, 20 de septiembre). Gimnasia higiénica. El mundo de los niños (Madrid), pp. 413-414.

Anuario Riera. (1904). Anuario Riera 1904. Anuario Riera.

Anuario Riera. (1905). Directorio madrileño. Anuario Riera.

Ávila, A. (2013). Moverse es vivir. Emilio Salvador López Gómez (1852-1936): La gimnasia en Sevilla. Diputacio\#n Provincial de Sevilla.

Bailly-Baillière, C. (1861, 15 de agosto). El Monitor de la Salud, 4(16), 181-192. https://ddd.uab.cat/record/174100

Busqué y Torró, D. S. (1865). Gimnástica higiénica, médica y ortopédica o el ejercicio considerado como medio terapéutico. Imp. Manuel Galiano. https://babel.hathitrust.org/cgi/pt?id=ucm.5322557867\&view=1up\&seq=10

Carue, Ph. J. B. (1868). Traité practique de gymnastique de chambre higiénique et médical a l'usage de deus sexes. Chez de l'auteur Rue Sainte-Appline. https://gallica.bnf.fr/ark:/12148/bpt6k374117p/f13.item

Carue, Ph. J. B. (1880). Tratado práctico de gimnástica higiénica para ambos sexos (4º ed.) Editorial en Casa del autor.

Chapman, D. L. (1994). Sandow the magnificent: Eugen Sandow and the beginnings of bodybuilding. University of Illinois Press.

Cleriot, E. (1900). Manual de gimnástica higiénico-educativa: Para usar con acierto la polea universal. Imp. de los hijos de M. G. Hernández.

Cleriot, E. (1901, 1 de abril). Método de gimnasia sueca. La Educación Física Nacional, 18, 1-2.

Cleriot, E. (1905, 30 de diciembre). La gimnástica en el hogar. La Ciudad Lineal (Madrid), pp. 1-2.

De las Barreras, J. (1903). Los ejercidos gimnásticos en el bello sexo. Publicaciones de Los Deportes.

De Vallieres, L. (ca. 1907). La gimnasia en jardines y habitaciones. Saturnino Calleja.

Editorial El País. (1893, 3 de mayo). Noticias. El Pais (Madrid), p. 2.

Ernst, F. G. (1861). The Portable Gymnasium: A Manual of Exercises, Arranged for Self-Instruction in the Use of the Portable Gymnasium: P. Grant \& C ${ }^{0}$. https://wellcomelibrary.org/item/b20399789\#?c=0\&m=0\&s=0\&cv=1 $4 \& \mathrm{z}=-1.1617 \% 2 \mathrm{C} 0 \% 2 \mathrm{C} 3.3233 \% 2 \mathrm{C} 1.6815$

Ferrer, D. (1900, 21 de enero). Aparatos modernos. Los Deportes (Barcelona), pp. 36-37.

Ferrer. E. (1894). Resumen de lecciones teóricas y prácticas de gimnástica. Curso de 1893-94, Imp. B. Fábregues. Mahón: Impresor de la Real Casa.

García-Fraguas, J. E. (1894). Tratado racional de gimnástica y de los ejercicios y juegos corporales..., t. II Teoría general de la gimnástica y del Sport. Casa editorial y Lib. de la Viuda de Hernando y Cia.

Gimnasia doméstica (1893, 9 de marzo). Gimnasia doméstica. El Liberal (Madrid), p. 4.

Gimnasia doméstica (1894, 17 de marzo). Gimnasia doméstica. El País (Madrid), p. 4.

Herrera, A. (2018). Fuentes y enfoques del periodismo de José Martí en el mensuario La América. Fundación Cultural Enrique Loymaz.

Kumlien, L. G. (1907). La gimnasia para todos. Librería Gutemberg de José Ruiz.

Kumlien, L. G., y Andre, E. (1904). La gimnasia sueca. Manual de gimnasia racional al alcance de todos y para todas las edades. Viuda de C. Bouret.

L'Ilustration, Journal Universel (1858. julio-diciembre). Gymnase Pichert. 32, 320. https://hdl.handle.net/2027/uc1 .c046857811 ?urlappend $=\% 3$ Bseq $=330$

Llaverías, A. (1904, 29 de octubre). A vuela pluma. Los Deportes (Barcelona), p. 684.

López Gómez, S. (1873). El gimnasio. Tratado teórico-práctico de todos los principios y reglas de aplicación a esta importante parte de la higiene. Imp. de R. Baldaraque. 
Martí, J. (1883, marzo). El gimnasio en casa. La América (Nueva York), 18, p. 240.

Martínez (1893, 3 de enero). Gimnasia higiénica. El Diluvio (Barcelona), p. 60.

Martínez Díaz, E. (1891). Gimnasia de higiene en casa: Polea "Sublime", perfeccionada para más de cien posiciones distintas. Tip. Tipografía de Andrés Sáez.

Martínez Díaz, E. (1893). Gimnasia de higiene en casa. Polea "SUBLIME" perfeccionada para más de cien movimientos diferentes (prospecto publicitario). Armería de Luys Vives y $C^{a}$.

Martínez Díaz, E. (ca. 1900). Gimnasia higiénico-doméstica. Polea Sublime. Lit. E Pérez.

Masjuan, E. (2006). Medis obrers i innovació cultural a Sabadell (1900-1939): L'altra aventura de la ciutat industrial. Universitat Autònoma de Barcelona.

Medel, F. (1900, 22 de noviembre). Noticias generales. Gimnasio. Diario de Murcia, p. 3.

Molina, E. (1900, 15 de septiembre). Sandow. El Liberal (Madrid), p. 4.

Morais, D. G. (2013). Branding Iron: Eugen Sandow's “Modern” Advertising Strategies, 1887-1925. Journal of Sport History, 40(2), 193-214.

Palomo, A. (1905, 11 de noviembre). Mercantilismo de fin de siglo. Los Deportes (Barcelona), 730-731.

Pastor, J. L. (1997). El espacio profesional de la educación física en España: Génesis y formación (1883-1961). Universidad de Alcalá de Henares.

Pastor, J. L. (2001). De funámbulos, gimnasiarcas y profesores de educación física (un relato circunstancial y tendencioso). Pila Teleña.

Pastor, J. L. (2003). Gimnástica. De la inopia conceptual a la utopía metodológica. Librerías Deportivas Esteban Sanz.

Pastor, J. L. (2015). Las metodologías educativas en la Europa continental en la que se educó Pierre de Coubertin: La gimnástica del siglo XIX y los materiales como criterio metodológico fundamental. Citius, Altius, Fortius: Humanismo, Sociedad y Deporte: Investigaciones y ensayos, 8(1), 123-155. http://cdeporte.rediris.es/revcaf/Nu meros\%20de\%20revista/Vol\%208\%20n1/Vol8_n1_PastorPradillo.pdf

Paz, E. (1873a, 1 de enero). Gimnasio doméstico graduado. El Americano (París), p. 698.

Paz, E. (1873b, 27 de enero). Gimnasio doméstico graduado. El Americano (París), p. 748.

Paz, E. (1888). Pequeño curso de gimnasia de salón sin aparatos. Lib. de la Enseñanza.

Pichery, J-L. (1857). Éducation du corps. Manuel de gymnastique hygiénique et médicale du gymnase de cambre Pechery. Chez J. B. Baillière et fils.

Polea "sublime" (1904, 20 de diciembre). Gimnasia perfecta. Polea "Sublime". El Imparcial (Madrid), p. 4.

Polea gentil gradual (1900). Gimnasia higiénica á domicilio, polea gentil gradual con privilegio exclusivo por veinte años, imprescindible para la reconstitución de fuerzas y precita por las principales notabilidades médicas. Bazar quirúrgico de Don Alonso Senmarti.

Polea higiénica (1904, 7 de noviembre). Polea Higiénica. Heraldo de Madrid (Madrid), p. 4.

Polea sublime (1904, 18 de mayo). Para la gimnasia en casa. El País (Madrid), p. 4.

Romero, V. (1905). Cartilla-compendio de gimnasia racional a pie firme y manos libres, Imp. de los Hijos de M. G. Hernández.

Royo Vilanova, L. (1892, 4 de mayo). Gimnasia con aparatos. La Semana Cómica (Barcelona), pp. 274-275.

Saimbraum (1912). Salud, fuerza y belleza por medio de la gimnasia sueca. Sociedad General de Publicaciones.

Sánchez Somoano, J. (1883a). Gran gimnasio higiénico. Imp. de Manuel Minuesa de los Ríos.

Sánchez Somoano, J. (1883b). Tratado de gimnasia pedagógica para uso de las escuelas de primera y segunda enseñanza e institutos. Imp. de Manuel Minuesa de los Ríos. http://bdh-rd.bne.es/viewer.vm?id=0000084149\&page=1

Sánchez Somoano, J. (1886). Nuevo método de gimnástica racional con la polea sistema Sánchez con patente de invención para veinte años. Imp. de Manuel Minuesa de los Ríos.

Sánchez Somoano, J. (1895). Gimnasia doméstica. Poleas. Imp. Vda. de M. Minuesa de los Ríos. 
MHSALUd, ISSN: 1659-097X, 18(1), ENERo-Junio, 2021, PP 1-30

TORREBADELLA-FLIX

Sandow, E. (1892, 12 de diciembre). El rey de los atletas. Ejercicios atléticos de Sandow en el Trocadero. La Ilustración Artística (Barcelona), pp. 5 y 10.

Sandow, E. (1905, 10 de octubre). Sandow. Los Deportes (Barcelona), p. 370.

Sardá, A. (1882, 1 de octubre). Gimnasia. Instrucción para la mujer (Madrid), pp. 225-227.

Schreber, D. G. M. (1864). Manual popular de gimnasia de sala médica e higiénica: o Representación y descripción de los movimientos gimnásticos, no exigiendo ningún aparato para su ejecución, pueden practicarse en todas partes y por toda clase de personas de uno y otro sexo. Seguido de sus aplicaciones a diversas enfermedades. (E. Sánchez, Trans., 4ta ed.) Carlos Bailly - Bailliere.

Schreiber, J. (1884). Traité pratique de massage et de gymnastique médicale. Octave Doin. http://www.cfdrm.fr/Livre _Traite_pratique_de_massage_et_de_gymnastique_medicale_par_Schreiber_Ed_Doin_1884_Paris.htm

Soleirol de Serves, Le Roux, M. (1906). Manual de gimnasia racional y práctica. Lib. Edt. Bailly-Balliere.

Taboada, L. (1892, 25 de marzo). Gimnasia casera. El Imparcial (Madrid), p. 1.

Torrebadella-Flix, X. (2020). El gimnasio moderno en España y Francia. Una relación franco-española equidistante y divergente en el siglo XIX. RICYDE. Revista Internacional de Ciencias del Deporte, 16(60), 153-179. https:/ /doi.org/10.5232/ricyde2020.06004

Torrebadella-Flix, X., Rivero-Herraiz, A. y Sánchez-García, R. (2019). When the Elites Began Going to the Gym: The Professional and Social Spaces of the First Hygienic Gymnasiums in Madrid, 1860-69. The International Journal of the History of Sport, 36 (15-16), 1347-1371. https://doi.org/10.1080/09523367.2019.1691531.

Torrebadella, X. (2011). Repertorio bibliográfico inédito de la educación física y el deporte en España (1800-1939). Fundación Universitaria Española.

Torrebadella, X. (2014). La influencia de la profesión médica en la educación física española del siglo XIX: Análisis social del Manual popular de gimnasia de sala, médica e higiénica del Dr. Schreber. Cultura, Ciencia y Deporte, 9(26), 163-176. http://dx.doi.org/10.12800/ccd.v9i26.434

Torrebadella, X. y López-Villar, C. (2016). Las primeras profesoras de gimnástica en España. Profesión liberal y coartada durante el siglo XIX. RICYDE. Revista Internacional de Ciencias del Deporte, 46, 423-442. http://dx. doi.org/10.5232/ricyde2016.04606

Ugarde, L. (ca. 1906). Manual práctico de gimnasia de jardin y salón. La higiene por medio de los ejercicios razonados, sin necesidad de ningún aparato. Barcelona: Editor Salvador Manero Bayarri.

Un viejo setentón [José Hernández Ardieta] (ca.1899). ¡Cien años de vida sana! Longevidad: arte de vivir mucho tiempo sin molestias ni enfermedades,... Manuel Soler.

Vicente-Pedraz, M., \& Brozas-Polo, M. (2017). El triunfo de la regularidad: Gimnasia higiénica contra acrobacia en la configuración física escolar en la segunda mitad del siglo XIX. Revista Brasilera do Sporte. 39(1), 49-55. http ://dx.doi.org/10.1016/j.rbce.2015.10.006

Vicente-Pedraz, M. y Torrebadella-Flix, X. (2019). Los primeros gimnasios higiénicos: Espacios para sanar y corregir el cuerpo. Disparidades. Revista de Antropologia, 74(1): e011. https://doi.org/10.3989/dra.2019.01.011

Waller, D. (2011). The Perfect Man: The Muscular Life and Times of Eugen Sandow, Victorian Strongman. Victorian Secrets.

Whitely (1901, 11 de marzo). The Whitely Health Exerciser. El Liberal (Madrid), p. 4.

\section{Notas}

[1] Declaración de propiedad. Todas las imágenes incorporadas que figuran como "propiedad particular" son de documentos originales y particulares de la colección del autor, realizadas exprofeso para ser reproducidas en el artículo "El gimnasio en casa (1861-1912): ¿De una moda a estilo de vida saludable?” en MHSalud: Revista en Ciencias del Movimiento Humano y Salud.

[2] Las imágenes de la colección Hemeroteca de la Biblioteca Nacional de España (HBNE) se comparten con una licencia: Reconocimiento-NoComercial-CompartirIgual 4.0 Internacional de Creative Commons. Para más información sobre 
la licencia de uso para las imágenes de la colección HBNE consulte el siguiente enlace: http://www.bne.es/es/Navega cionRecursiva/Pie/avisoLegal/

[3] Ver la colección de Arxiu de Revistes Catalanes Antigues: https://arca.bnc.cat/arcabib_pro/en/inicio/inicio.do

\section{BY-NC-ND}

